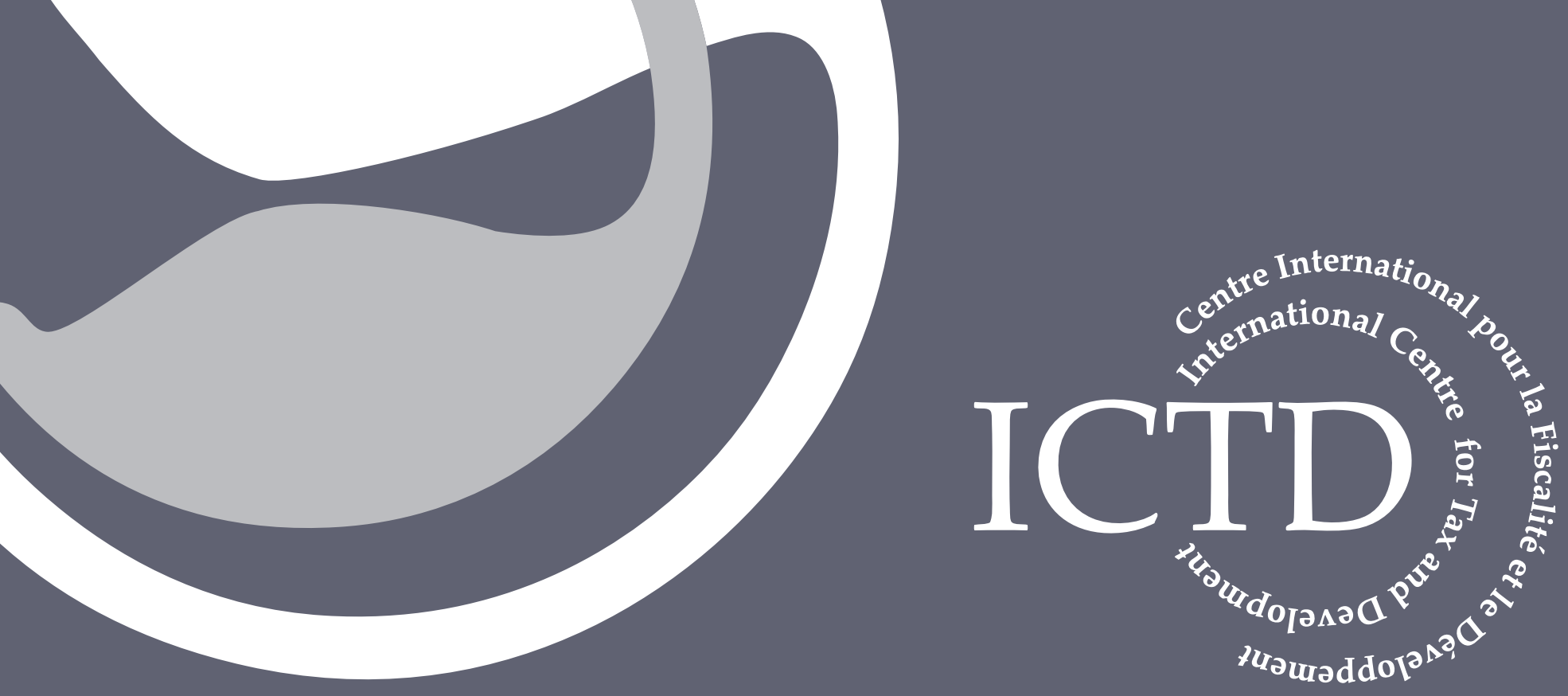

Research Report 2

\title{
Iressons for International Irax Reform from the US State Experience under Formulary Apportionment
}

Kimberly Clausing

March 2014 
ICTD Research Report 2

Lessons for International Tax Reform from the US State Experience under Formulary Apportionment

Kimberly Clausing

March 2014 
Lessons for International Tax Reform from the US State Experience under Formulary Apportionment Kimberly Clausing

ICTD Research Report 2

First published by the Institute of Development Studies in March 2014

(C) Kimberley Clausing 2014

ISBN: 978-1-78118-163-8

The author of this paper grants to the IDS and the ICTD a perpetual, irrevocable, worldwide, royalty-free, non-exclusive licence, or sublicence, to reproduce, communicate to the public, use, adapt, publish, distribute, display and transmit the work in any and all media, and to sublicense others (including the Crown) to reproduce, communicate to the public, use, adapt, publish, distribute, display and transmit the work in any and all media, for non-commercial purposes and with appropriate credit being given to the author and ICTD funders.

A catalogue record for this publication is available from the British Library.

This work has been licensed by the copyright holder for distribution in electronic format via any medium for the lifetime of the OpenDocs repository for the purpose of free access without charge and can be found at http://opendocs.ids.ac.uk/opendocs/

Also available from:

International Centre for Tax and Development,

Institute of Development Studies,

Brighton BN1 9RE, UK

Tel: +44 (0) 1273915637 Fax: +44 (0) 1273621202

E-mail: info@ictd.ac

Web: www.ictd.ac

IDS is a charitable company limited by guarantee and registered in England (No. 877338) 


\title{
Lessons for International Tax Reform from the US State Experience under Formulary Apportionment
}

\author{
Kimberly Clausing
}

\begin{abstract}
Summary
This work undertakes a comprehensive analysis of the US state experience under formulary apportionment of corporate income. While formulary apportionment eliminates the possibility of shifting income across states through accounting strategies that manipulate where income is booked, it may heighten the tax responsiveness of formula factors. The present analysis uses the substantial variation in corporate tax policy decisions of US states over the period 1986 to 2012 to understand the consequences of formulary apportionment better. It examines the effects of policy choices regarding tax rates, formula weights, and other parameters on economic activity, estimating the tax sensitivity of employment, investment, and sales. With the inclusion of adequate control variables, results indicate that economic activity has not been particularly sensitive to US state corporate tax policy choices, especially in recent years. Still, tax policy choices have important effects on corporate tax revenues. These results suggest important lessons regarding possible international adoption of formulary apportionment.
\end{abstract}

Keywords: tax competition; formulary apportionment; unitary taxation; corporate taxation; international taxation; state taxation; corporate tax revenue.

Kimberly Clausing is the Thormund A. Miller and Walter Mintz Professor of Economics at Reed College in Portland, Oregon, USA. 


\section{Contents}

Summary 3

Acknowledgements $\quad 5$

Acronyms $\quad 5$

Introduction $\quad 6$

$\begin{array}{lll}\text { What can we learn from US states? } & 7\end{array}$

$2 \quad$ Prior work 9

3 Specifications 10

4 Results 14

4.1 Employment activity 14

4.2 Investment activity 16

$\begin{array}{ll}4.3 \text { Sales activity } & 18\end{array}$

4.4 Discussion of activity results 20

4.5 Government corporate tax revenue 20

$\begin{array}{ll}4.6 \text { Extensions } & 23\end{array}$

$\begin{array}{lll}4.7 & \text { Policy endogeneity concerns } & 23\end{array}$

$5 \quad$ Conclusions and policy implications 24

Appendices

Appendix 1 Data sources 26

Appendix 2 Results for pooled (OLS) and region effects specifications 28

Appendix 3 Policy probit specifications 32

$\begin{array}{ll}\text { References } & 35\end{array}$

Tables

Table $1 \quad$ Variable descriptions, definitions, and summary statistics 11

Table $2 \quad$ Employment regressions 15

$\begin{array}{lll}\text { Table } 3 & \text { Capital expenditure regressions } & 17\end{array}$

Table $4 \quad$ Sales regressions 19

Table $5 \quad$ Corporate state income tax revenue/GSP regressions 22

Table A1 Employment regressions 28

Table A2 Capital expenditure regressions $\quad 29$

Table A3 Sales regressions 30

Table A4 Corporate state income tax revenue/GSP regressions 31

$\begin{array}{ll}\text { Table A5 } & \text { Probit regressions on probability of raising apportionment weight } \\ & \text { on sales }\end{array}$

Table A6 Probit regressions on probability of lowering corporate tax rate 33

Figures

Figure 1

Figure 2

Share of states using different formulas

Corporate profits and state corporate tax revenues as a share of GDP 21 


\section{Acknowledgements}

I am grateful for funding from the International Centre on Tax and Development, supported by the UK Government's Department for International Development (DFID) and the Norwegian Agency for Development Cooperation (NORAD). I am thankful to Sarah Brauner for extremely capable research assistance and Brett Collins of the US Internal Revenue Service for compiling the historical data on pass-through organisations. I received helpful comments from Ruud de Mooij, participants at the National Tax Association Conference, and participants in the International Centre for Tax and Development's Research Programme on Unitary Taxation of Developing Countries. Finally, I would like to thank Polia Petkova for work on her senior thesis that contributed to the US state tax policy data collection as well as my interest in this topic.

\section{Acronyms}

$\begin{array}{ll}\text { BEA } & \text { Bureau of Economic Analysis } \\ \text { GDP } & \text { Gross Domestic Product } \\ \text { GSP } & \text { Gross State Product } \\ \text { IRS } & \text { Internal Revenue Service } \\ \text { NAICS } & \text { North American Industry Classification System } \\ \text { SIC } & \text { Standard Industrial Classification } \\ \text { UDITPA } & \text { Uniform Division of Income for Tax Purposes }\end{array}$




\section{Introduction}

There is an understandable desire to improve systems for taxing international corporate income. Presently, tax systems rely on separate accounting, whereby multinational corporations account separately for income and expenses earned in each taxing jurisdiction. Numerous observers have vocally criticised this system: it is difficult to establish the true source of income, and multinational firms have become increasingly adept at shifting income from highly-taxed jurisdictions to more lightly-taxed ones. ${ }^{1}$ Governments have often attempted to curb such income-shifting behaviour through regulations, yet these regulations are complicated, costly to administer, and often ineffective. Multinational corporations are also not content: they complain of high compliance costs, substantial uncertainty regarding ultimate tax burdens, and unfair taxbased competitive pressures in the global marketplace.

In this environment, formulary apportionment has emerged as a compelling alternative for international tax reform. Under formulary apportionment, income is assigned to each taxing jurisdiction based on a simple formula. This system has the potential for large benefits in terms of simplicity, administration, and curbing tax base erosion. However, formulary apportionment may create its own practical difficulties. For example, there are accounting concerns about the measurement of the formula components and the tax base, as well as legal concerns about the definition of a consolidated business and the impact on international tax treaties.

Beyond the pragmatic details of implementation, there are also important concerns that a formulary approach will generate its own tax distortions. For example, multinational corporations may respond to formulary apportionment by moving the activities that are used to determine the assignment of income to low-tax jurisdictions. Also, there are important questions about the revenue consequences of formulary apportionment.

This paper uses the US state experience with formulary apportionment to inform both of these concerns. In particular, it considers the tax sensitivity of formula factors under formula apportionment, and it evaluates the determinants of corporate tax revenue under a formulary system. The empirical analysis focuses on US state corporate tax policy choices over the period 1986 to 2012.

In the context of international tax policy choices, an analysis of the US state experience may seem peculiar. Yet the US state experience may provide insight into the dynamics of international tax competition. US states are more economically integrated than countries are presently, but the extent of economic integration among US states demonstrates one possible future for global economic integration.

Further, US states provide a useful source of policy variation for understanding the consequences of formulary apportionment, since they retain a great deal of autonomy on corporate tax policy choices. ${ }^{2}$ US states choose tax rates, formulas, and other rules independently, and states have not shied away from policy changes. These types of policy

Empirical evidence on income shifting is well known; see the survey articles of De Mooij (2005) and De Mooij and Ederveen (2008). Clausing $(2009,2011)$ indicates that income-shifting behaviour has high revenue costs for high-tax rate governments. This issue has received policy attention of late, with hearings in the US Congress and UK Parliament, as well as attention in recent $\mathrm{G} 8$ and $\mathrm{G} 20$ meetings.

Still, a common (and economically significant) federal layer of taxation exists for US states. 
variation are used to understand better the consequences of formulary apportionment for both economic activity and revenue.

In terms of economic activity results demonstrate very little tax sensitivity, in contrast to some early studies of this question. The divergent findings may result in part from the longer time period under investigation in the present study. For example, as more and more states have engaged in tax competition by increasing sales factor weights and making other rules more favourable, the effect of individual state policy choices may have been muted. There is evidence in the early literature that states that increased sales weights gained employment at other states' expense. However, in the recent period, as more and more states have increased sales weights, there is no evidence of these effects persisting.

In terms of tax revenues, this analysis suggests that tax policy decisions are important. States that increase sales weights or allow elective features of their tax policy environment have lower tax revenues, while higher tax rates and 'throwback rules' are associated with higher corporate tax revenues.

Together with the results on activity, this result suggests important policy lessons for potential international adoption of formulary apportionment. In particular, under formulary apportionment countries will likely remain tempted by beggar-my-neighbour tax policy competition. Efforts to assure harmonised formulas and to protect the corporate tax base from erosion will still be important.

\section{What can we learn from US states?}

US states have a long experience with formulary apportionment of corporate income. After the US corporate income tax was adopted in the early twentieth century, US states realised the difficulty of separate accounting for income and expenses in each state in an environment when business activity is well-integrated across states. Thus, by the mid-twentieth century US states allocated national income to state jurisdictions by formula. ${ }^{3}$

At first, the common formula employed by US states was based on three factors, the share of a firm's payroll, assets, and sales in a particular state:

$$
\operatorname{Tax}_{\mathrm{i}}=t_{i} \Pi_{U S}\left[1 / 3\left(\frac{A_{i}}{A_{U S}}+\frac{S_{i}}{S_{U S}}+\frac{P_{i}}{P_{U S}}\right)\right]
$$

where the subscript $i$ indicates a particular state and the subscript US indicates the United States, $t_{i}$ is the state tax rate, $\Pi_{u s}$ is US profit, $A$ is assets, $S$ is Sales, and $P$ is payroll. Observers have noted that a formulary system creates an implicit tax on the factors used in the formula, thus discouraging assets and employment in high-tax locations.

In part due to these concerns, as well as business lobbying, many states have increased the weight on their sales factor in recent decades, often doubling it relative to weights on other factors. Some states have even adopted sales-only formulas, where tax liabilities are calculated as:

A detailed history is provided in Hellerstein and Hellerstein (1998). 


$$
\operatorname{Tax}_{i}=t_{i} \Pi_{U S}\left(\frac{S_{i}}{S_{U S}}\right)
$$

Indeed, over the period of the study (1986-2012), there have been many changes in state formulas for allocating corporate income. In 1986, 80 per cent of states that taxed corporate income used an equal-weighted formula, and 20 per cent had higher weights on sales. By 2012 , in contrast, only 17 per cent of states that taxed corporate income used an equal-weighted formula; the rest had formulas with a larger weight on sales. In recent years, there has been a spurt of states adopting single-sales formulas, where the entire weight is on the sales factor. Figure 1 shows this experience.

\section{Figure 1 Share of states using different formulas}

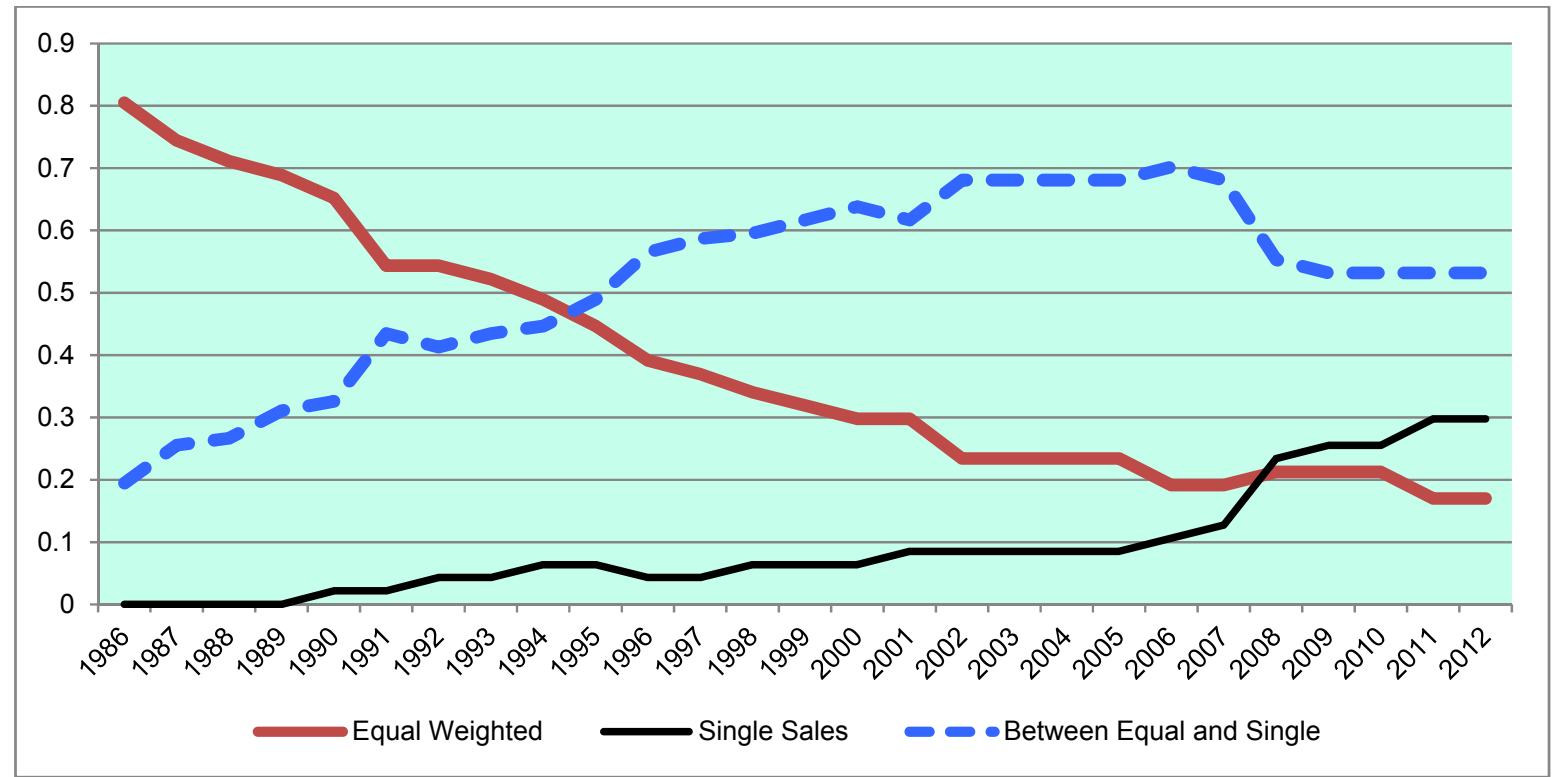

Note: The figure shows the share of states with a $1 / 3$ weight on sales (equal-weighted formula with sales, assets, and payroll), with heavier weights on sales (between equal and single), and with single-factor sales formulas. Data on formulas was compiled from various sources, described in detail in Appendix 1.

There is also substantial variation between states in other corporate tax policy rules: whether combined reporting is required, whether there are throwback rules that tax 'nowhere' income, whether options are offered between formula types or reporting requirements, and so on. Further, states have frequently experimented with changes in corporate tax rates as well, although corporate tax rates for the average of all states are relatively stable over time, averaging 7.2 per cent in 1986, and 6.6 per cent in 2012 .

While US states provide a valuable and diverse set of corporate tax policy experiences under formulary apportionment to study, there are also important caveats to bear in mind. US states typically choose low tax rates, and the response of economic activity to tax rate differences is likely to be larger and more apparent at higher tax rates.

Also, US states exist within a common federal system, and there is no analogous supranational 
body in most cases. ${ }^{4}$ A common federal system makes it easier to determine the tax base to which the formula should apply, since most US states begin with the federal definition of income as their baseline tax base. Still, the common federal system itself heightens tax competition pressures, since it facilitates economic mobility of all types. Footloose firms have an easier time relocating across states than across national boundaries, and domestic product competition is fiercer than its international counterpart - prices are more uniform and comparable, there is no possibility of exchange rate fluctuations, information is more available, and goods mobility is more seamless. For these reasons, one would expect tax competition to be fiercer within countries than between countries, so this may also reduce the applicability of the US state experience.

\section{Prior work}

This paper will build on the insights of past work on formulary apportionment, both internationally and at the state level. Prior work on the international implications of formulary systems includes Avi-Yonah and Clausing (2008), Avi-Yonah et al. (2009), De Waegenaere and Sansing (2008), Devereux and Loretz (2008a, 2008b), Eichner and Runkel (2008), Fuest et al. (2007), Hines (2010), and Pethig and Wagener (2007).

Regarding the US state experience, state incentives to change formulas are well known: Anand and Sansing (2000), Edmiston (2002), and Pinto (2007) generate models of formula choice, and Omer and Shelley (2004) empirically document the trend towards higher sales factor weights. Recently, Chirinko and Wilson (2010) consider the role of political contributions and state tax policy competition over the period 1988-2006. They find that policymakers are sensitive to campaign contributions, and their results document the nature of tax competition among states. Results also indicate the importance of including state-specific fixed effects in specifications; without this inclusion, some of the results are perverse.

Mintz and Smart (2004) have a clear and compelling study of the effects of formulary apportionment on income-shifting incentives, making use of the Canadian example. Some, but not all, multijurisdictional firms are required to allocate income to Canadian provinces by formula. Using data from the Canadian Customs and Revenue Agency over the period 1986-99, they find that taxable income is far less sensitive to tax rates, indicating less income shifting, for firms that are required to allocate income by formula.

The effects of formula choice on economic activity have also received some attention, and three studies employ cross-state-level data to consider the relationship between formula choice and employment, sales, and investment. First, Goolsbee and Maydew (2000) consider employment effects over the period 1978-94: they find evidence that employment is sensitive to the weight on employment in the formula, and there is evidence of tax competition among states whereby states gain employment at the expense of other states.

Second, Gupta and Hofmann (2003) consider the impact of formula choices, tax rates, and other policy choices such as investment incentives on capital expenditure effects over the period 1983-96. In the specifications that employ fixed effects, the effects of tax policy measures are

One possible exception would be the European Union, although the role of the EU government is substantially smaller than the US federal government, and it is likely to remain so for the foreseeable future. 
smaller than in other specifications, but still statistically significant. ${ }^{5}$ They note that the revenue losses associated with lower tax burdens are likely more consequential than the effects on investment magnitudes.

Third, Klassen and Shackelford (1998) consider the effect of sales weights in the apportionment formula on manufacturing revenue, their measure of sales, over the period 1983-91. They find that in throwback states, but not in others, manufacturing revenues are sensitive to the tax rate applied to sales. Their analysis is confined to separate estimates of cross-sections of states for each year in their sample; they do not employ panel data techniques. All three of these studies focus on a period that excludes the recent time period of rapid policy changes, so they necessarily utilise less variation than the present analysis. ${ }^{6}$

There has been some promising work on state corporate tax revenues, including Gupta et al. (2009), Cornia et al. (2005), Fox and Luna (2005), and Mazerov (2001). Gupta et al. (2009) is the most fully developed analysis. The authors undertake a study of the determinants of state corporate tax revenues over the period 1982-2002; their data set allows controls for most important considerations. They find that states that increase sales factor weights have lower corporate revenues, but revenues increase with the tax rate. Throwback rules and broader definitions of business income increase revenues, but combined reporting has no effect. The authors note that the policy environment has continued to evolve rapidly in the years since their study, so including an additional decade of data in the present study is likely useful.

Both the economic activity and revenue studies discussed above focus on earlier periods, and the present study will allow a consideration of both recent changes and longer-run effects from early changes. Further, the present work will benefit from taking a comprehensive approach that considers the effects of both formula choices and other tax policy choices on a wide range of economic outcomes.

There will also be essential methodological improvements over prior work. For example, not all prior studies employ state-specific fixed effects, yet this is important in order to prevent spurious statistical correlations that could easily result from omitted variables. For example, if states that are particularly business-friendly are also more likely to weight the sales factor heavily in their formulas, and one does not include state fixed effects, then one would risk attributing increases to economic activity solely to the increase in the sales factor, when other aspects of states' policies may be far more important.

\section{Specifications}

The present analysis will undertake an investigation of how policy decisions by US states under formulary apportionment affect US state government corporate income tax revenues as well as economic activities across US states. Dependent variables are defined and summarised in Table 1. They fall into four categories: measures of employment, investment, sales, and government revenues.

\footnotetext{
5 Results imply that states with a property burden (the multiple of their tax rate and the formula weight on property) one percentage point higher are associated with 0.09 per cent lower new capital expenditure. There is some evidence that there is greater tax rate sensitivity in states that employ throwback rules or unitary taxation, but in general these effects are quite modest.

$6 \quad$ In this analysis, I check results from baseline specifications for early years in the sample, finding that some results are sensitive to the time period studied; economic activity appears more tax sensitive in early years. Possible reasons for this finding are discussed below.
} 
Table 1 Variable descriptions, definitions, and summary statistics

\begin{tabular}{|c|c|c|c|c|c|}
\hline Name & Definition & Source & No. & Mean & St.Dev. \\
\hline \multicolumn{6}{|c|}{ Dependent variables: } \\
\hline $\begin{array}{l}\text { Employment } \\
\text { (Inem) }\end{array}$ & $\begin{array}{l}\text { Thousands of jobs, incl. full and part time } \\
\text { employees, sole proprietors, partners }\end{array}$ & $\begin{array}{l}\text { Bureau of Economic } \\
\text { Analysis }\end{array}$ & 1326 & 3,063 & 3,322 \\
\hline $\begin{array}{l}\text { Capital } \\
\text { expenditure } \\
\text { (Inkexp) }\end{array}$ & $\begin{array}{l}\text { Total capital expenditure for plant and equipment, } \\
\text { in mil. \$ }\end{array}$ & $\begin{array}{l}\text { Annual Survey of } \\
\text { Manufacturers }\end{array}$ & 1273 & 2,495 & 2,985 \\
\hline $\begin{array}{l}\text { Sales } \\
\text { (Insales) }\end{array}$ & Value of shipments of all products, in mil. \$ & $\begin{array}{l}\text { Annual Survey } \\
\text { Manufacturers }\end{array}$ & 1275 & 76,800 & 87,300 \\
\hline $\begin{array}{l}\text { Corporate tax } \\
\text { revenue }\end{array}$ & $\begin{array}{l}\text { Taxes on income of corporations and } \\
\text { businesses, as share of GSP (in \%) }\end{array}$ & US Census Bureau & 1325 & 0.340 & 0.250 \\
\hline \multicolumn{6}{|c|}{ Explanatory variables: tax policy parameters } \\
\hline $\begin{array}{l}\text { Payroll burden } \\
\text { (payburden) }\end{array}$ & $\begin{array}{l}\text { Multiple of corporate tax rate and payroll weight } \\
\text { in formula }\end{array}$ & $\begin{array}{l}\text { Various } \\
\text { (appendix) }\end{array}$ & 1244 & .0189 & .0096 \\
\hline $\begin{array}{l}\text { Asset burden } \\
\text { (assetbur) }\end{array}$ & $\begin{array}{l}\text { Multiple of corporate tax rate and asset weight in } \\
\text { formula }\end{array}$ & $\begin{array}{l}\text { Various } \\
\text { (appendix) }\end{array}$ & 1244 & .0189 & .0096 \\
\hline Salesburden & $\begin{array}{l}\text { Multiple of corporate tax rate and sales weight in } \\
\text { formula }\end{array}$ & $\begin{array}{l}\text { Various } \\
\text { (appendix) }\end{array}$ & 1244 & .0383 & .0199 \\
\hline Throwback & Dummy variable for state throwback rule & $\begin{array}{l}\text { Various } \\
\text { (appendix) }\end{array}$ & 1245 & .560 & .497 \\
\hline Combrep & $\begin{array}{l}\text { Dummy variable for state requiring combined } \\
\text { reporting }\end{array}$ & $\begin{array}{l}\text { Various } \\
\text { (appendix) }\end{array}$ & 1237 & .379 & .485 \\
\hline Pitax & Personal income tax, top rate & $\begin{array}{l}\text { Various } \\
\text { (appendix) }\end{array}$ & 1352 & .059 & .031 \\
\hline Licgsp & $\begin{array}{l}\text { Corporate licence and other fees as a share of } \\
\text { GSP }\end{array}$ & US Census Bureau & 1325 & .064 & .165 \\
\hline Throwsb & Multiple of throwback dummy and sales burden & Constructed & 1231 & .0192 & .0207 \\
\hline Forchoice & Dummy if corporations have a choice of formula & $\begin{array}{l}\text { Various } \\
\text { (appendix) }\end{array}$ & 1249 & .085 & .279 \\
\hline Crchoice & $\begin{array}{l}\text { Dummy if firms have choice of combined } \\
\text { reporting }\end{array}$ & $\begin{array}{l}\text { Various } \\
\text { (appendix) }\end{array}$ & 1237 & .150 & .358 \\
\hline Rate & Corporate tax rate, top rate & $\begin{array}{l}\text { Various } \\
\text { (appendix) }\end{array}$ & 1368 & .070 & .029 \\
\hline Salesw & Weight on sales in formula & $\begin{array}{l}\text { Various } \\
\text { (appendix) }\end{array}$ & 1249 & .505 & .205 \\
\hline \multicolumn{6}{|c|}{ Explanatory variables: economic conditions parameters } \\
\hline Natlunem & National (US) unemployment rate & $\begin{array}{l}\text { Bureau of Labor } \\
\text { Statistics }\end{array}$ & 1377 & .061 & .015 \\
\hline Unem & State unemployment rate & $\begin{array}{l}\text { Bureau of Labor } \\
\text { Statistics }\end{array}$ & 1377 & .057 & .019 \\
\hline GSP & Gross State Product, mil. \$ & Bureau of Ec. Analysis & 1326 & 182,875 & 241,182 \\
\hline
\end{tabular}




\begin{tabular}{|c|c|c|c|c|c|}
\hline \multicolumn{6}{|l|}{ (lngsp) } \\
\hline $\begin{array}{l}\text { GSPPC } \\
\text { (lngsppc) }\end{array}$ & Gross State Product per capita, \$/person & Population data, Census & 1326 & 33,430 & 16,150 \\
\hline $\begin{array}{l}\text { Osurplus } \\
\text { (Inosurplus) }\end{array}$ & Business income of private enterprises, mil. \$ & Bureau of Ec. Analysis & 1326 & 65,850 & 90,100 \\
\hline \multicolumn{6}{|c|}{ Explanatory variables: structure of state economy } \\
\hline BA & $\begin{array}{l}\text { Share of state population with a Bachelor's } \\
\text { Degree (as \%) }\end{array}$ & US Census Bureau & 1377 & 24.1 & 5.89 \\
\hline Manufratio & $\begin{array}{l}\text { Ratio of total employment in the manufacturing } \\
\text { sector }\end{array}$ & Bureau of Ec. Analysis & 1324 & .1005 & .0458 \\
\hline Youngshare & Share of population 18 and under & US Census & 1300 & .255 & .023 \\
\hline Oldshare & Share of population 65 and over & US Census & 1300 & .126 & .020 \\
\hline Region Dummies & Dummies for states from various regions & From Crone (2005) & 1515 & Varies & Varies \\
\hline Share & $\begin{array}{l}\text { Share of business tax returns that are flow- } \\
\text { through entities }\end{array}$ & $\begin{array}{l}\text { US Internal Revenue } \\
\text { Service }\end{array}$ & 1150 & .680 & .096 \\
\hline \multicolumn{6}{|c|}{ Other variables used for policy probits } \\
\hline Meansalesw & Mean sales weight in state formulas, by year & Constructed & 1377 & .503 & .089 \\
\hline Meanrate & Mean corporate tax rate of states, by year & Constructed & 1377 & .070 & .002 \\
\hline Rep & $\begin{array}{l}\text { Dummy if Republicans control state legislative } \\
\text { and executive branches }\end{array}$ & $\begin{array}{l}\text { Klarner Politics Dataset } \\
\text { (appendix) }\end{array}$ & 1271 & .196 & .397 \\
\hline Dem & $\begin{array}{l}\text { Dummy if Democrats control state legislative and } \\
\text { executive branches }\end{array}$ & $\begin{array}{l}\text { Klarner Politics Dataset } \\
\text { (appendix) }\end{array}$ & 1271 & .243 & .429 \\
\hline Elecyr & Dummy variable if election year in state & US Statistical Abstract & 1316 & .273 & .446 \\
\hline Debtgsp & State debt as a share of GSP & $\begin{array}{l}\text { State Government } \\
\text { Finances }\end{array}$ & 1286 & .071 & .040 \\
\hline Aidgsp & State federal aid as a share of GSP & US Census & 1214 & .034 & .013 \\
\hline
\end{tabular}

The basic specifications relate the dependent variables to the explanatory variables as in the following equations, where $P$ is a vector of tax policy choices, $E$ and $S$ are vectors of control variables capturing the macroeconomic conditions of states and the structure of the state economy, and where i indicates states and $t$ indicates years.

$$
\begin{aligned}
& \text { Employment measure }_{i t}=\sum_{i} \alpha_{i}+\sum_{P} \beta_{p} P_{i t}+\sum_{E} \beta_{e} E_{i t}+\sum_{S} \beta_{s} S_{i t}+\varepsilon_{i t} \\
& \text { Investment measure }_{i t}=\sum_{i} \alpha_{i}+\sum_{P} \beta_{p} P_{i t}+\sum_{E} \beta_{e} E_{i t}+\sum_{S} \beta_{s} S_{i t}+\varepsilon_{i t} \\
& \text { Sales measure }_{i t}=\sum_{i} \alpha_{i}+\sum_{P} \beta_{p} P_{i t}+\sum_{E} \beta_{e} E_{i t}+\sum_{S} \beta_{s} S_{i t}+\varepsilon_{i t}
\end{aligned}
$$


Revenue measure $_{i t}=\sum_{i} \alpha_{i}+\sum_{P} \beta_{p} P_{i t}+\sum_{E} \beta_{e} E_{i t}+\sum_{S} \beta_{s} S_{i t}+\varepsilon_{i t}$

For this investigation, state-level policy choices are of most interest. It is hypothesised that the policy choices will typically affect revenues and economic activity in opposite directions; policies that increase tax burdens typically raise revenue but also discourage economic activity. For example, higher tax rates increase revenue as long as Laffer curve effects do not predominate, which is unlikely at the low levels of taxation of US states. ${ }^{7}$ But higher tax rates also raise the tax burden on any factors that are in the formula, presumably discouraging such activities in US states.

For example, following Goolsbee and Maydew (2000), the firm's marginal tax rate is the sum of the state tax rates over the states in which it operates. If all firms are taxed according to an equal-weighted formula, as in Equation 1, and states are indexed by $\mathrm{i}$, this becomes:

$\mathrm{T}=\frac{1}{3}\left[\sum_{i} t_{i} \frac{A_{i}}{A_{u s}}+\sum_{i} t_{i} \frac{S_{i}}{S_{u s}}+\sum_{i} t_{i} \frac{P_{i}}{P_{u s}}\right]$

If the firm moves workers from high-tax to low-tax states, it will reduce its marginal tax rate. Assuming that the total payroll is unchanged, moving payroll towards a particular low tax state (j) changes the firm's marginal tax rate as follows:

$$
\frac{\partial \mathrm{T}}{\partial P_{j}}=\left(\frac{1}{3 P_{u s}}\right)\left[t_{j}-\sum_{i \neq j} t_{i} \frac{P_{i}}{\sum_{i \neq j} P_{i}}\right]
$$

As long as the tax rate in the state with increased jobs is lower than the weighted average of other states' tax rates, the firm's marginal tax rate on US income declines.

US states have often increased the sales factor weights in recent decades. Indeed, the weight on the sales factor directly lessens the burden on other factors, and so one would expect taxsensitive firms to be more likely to locate productive factors (assets and employment) in high sales factor states. However, a higher sales weight will reduce corporate revenues for states where their asset and employment activity shares are higher than their sales shares. Indeed, dominant productive firms in local economies often lobby for increases in the sales factor in the formula.

In theory, if states consume roughly in line with their production, and if all states moved to a sales-only formula, both the overall tax burden for firms and state revenues would be unchanged. But since firms often lack nexus in a particular state, not all sales generate associated corporate tax revenues under the present system. Further, since states vary in their formula choices, firms may be able to lower their overall tax burden by taking advantage of these differences and altering the location of their activities accordingly.

Revenues will fall with increases in the tax rate if the elasticity of the tax base with respect to the tax rate is sufficiently large. Clausing $(2007,2008)$ finds that the revenue-maximising corporate tax rate is likely to be higher than the rates found in typical OECD countries. 
Discretionary features of the corporate tax policy environment may also lighten tax burdens on corporations as well as lower revenues. When firms are allowed to choose between different formulas, or to choose whether to utilise combined reporting, they are likely to make informed choices that lessen their tax burden.

Some states attempt to counter these revenue-reducing tax competition pressures. For example, some states employ throwback rules. States that use throwback rules require firms to pay tax on income that is untaxed in another state. Also, some US states require combined reporting; this can help ensure that large multijurisdictional firms do not avoid taxation by splitting themselves into separate corporations and manipulating transactions within the overall corporate group. In the present analysis, dummy variables are used to capture such features of the state corporate tax code.

Control variables will allow for the effects of the health of the state economy, structural features of the state economy, and time-specific and state-specific effects. All variables are described and summarised in Table 1; the data sources are described in detail in Appendix 1.

\section{Results}

\subsection{Employment activity}

Results from the employment specifications are in Table 2. Specifications (1) to (3) employ state fixed effects; column (1) is the most basic model, and columns (2) and (3) add more explanatory variables. Columns (4) to (6) repeat these specifications, adding year fixed effects in addition to state fixed effects. 
Table 2 Employment regressions, state fixed effects (1-3), state and year fixed effects (4-6)

Dependent variable: Ln of employment

\begin{tabular}{|c|c|c|c|c|c|c|}
\hline & (1) & (2) & (3) & (4) & (5) & $(6)$ \\
\hline payburden & $\begin{array}{l}-10.94^{*} \\
(0.566)\end{array}$ & $\begin{array}{c}1.191^{\star} \\
(0.313)\end{array}$ & $\begin{array}{l}-0.153 \\
(0.118)\end{array}$ & $\begin{array}{c}0.765^{*} \\
(0.338)\end{array}$ & $\begin{array}{c}1.221^{*} \\
(0.315)\end{array}$ & $\begin{array}{c}-0.201 \\
(0.111)\end{array}$ \\
\hline natlunem & $\begin{array}{l}-0.956^{\star} \\
(0.217)\end{array}$ & $\begin{array}{c}-0.812^{*} \\
(0.0978)\end{array}$ & $\begin{array}{c}-1.082^{*} \\
(0.0411)\end{array}$ & & & \\
\hline throwback & & $\begin{array}{c}-0.0273^{\star} \\
(0.00765)\end{array}$ & $\begin{array}{c}-0.00464 \\
(0.00287)\end{array}$ & & $\begin{array}{c}-0.0275^{*} \\
(0.00772)\end{array}$ & $\begin{array}{l}-0.00856 * \\
(0.00272)\end{array}$ \\
\hline combrep & & $\begin{array}{c}-0.0139^{*} \\
(0.00406)\end{array}$ & $\begin{array}{r}-0.000428 \\
(0.00157)\end{array}$ & & $\begin{array}{c}-0.0156^{*} \\
(0.00414)\end{array}$ & $\begin{array}{l}-0.00218 \\
(0.00149)\end{array}$ \\
\hline Ingsppc & & $\begin{array}{c}0.369^{\star} \\
(0.00573)\end{array}$ & $\begin{array}{c}-0.690^{\star} \\
(0.0155)\end{array}$ & & $\begin{array}{c}0.365^{*} \\
(0.0353)\end{array}$ & $\begin{array}{c}-0.681^{*} \\
(0.0176)\end{array}$ \\
\hline pitax & & & $\begin{array}{c}0.180^{*} \\
(0.0629)\end{array}$ & & & $\begin{array}{c}0.158^{*} \\
(0.0605)\end{array}$ \\
\hline licgsp & & & $\begin{array}{l}-6.808^{\star} \\
(1.881)\end{array}$ & & & $\begin{array}{l}-9.248^{*} \\
(1.771)\end{array}$ \\
\hline Ingsp & & & $\begin{array}{c}0.859^{*} \\
(0.0111)\end{array}$ & & & $\begin{array}{c}0.866^{*} \\
(0.0105)\end{array}$ \\
\hline ba & & & $\begin{array}{l}0.000402 \\
(0.00045)\end{array}$ & & & $\begin{array}{c}0.00101^{*} \\
(0.00048)\end{array}$ \\
\hline manufratio & & & $\begin{array}{c}0.928^{*} \\
(0.0481)\end{array}$ & & & $\begin{array}{c}0.711^{*} \\
(0.0556)\end{array}$ \\
\hline youngshare & & & $\begin{array}{c}-1.419^{\star} \\
(0.0801)\end{array}$ & & & $\begin{array}{c}-1.777^{\star} \\
(0.0840)\end{array}$ \\
\hline oldshare & & & $\begin{array}{c}-0.248 \\
(0.127)\end{array}$ & & & $\begin{array}{l}-0.767^{\star} \\
(0.143)\end{array}$ \\
\hline Fixed effects? & yes & yes & yes & yes & yes & yes \\
\hline Year effects? & no & no & no & yes & yes & yes \\
\hline$N$ & 1122 & 1102 & 1032 & 1122 & 1102 & 1032 \\
\hline$R^{2}$ & 0.258 & 0.853 & 0.981 & 0.832 & 0.857 & 0.984 \\
\hline
\end{tabular}

Standard errors in parentheses

$p<0.05$

In all cases apart from the first specification, the payroll burden variable, which is the simple multiple of the payroll weight and the tax rate, is either statistically insignificant or unexpectedly positive. In the first (and most bare-bones) specification, however, it is both negative and statistically significant.

Throwback rules and combined reporting requirements are negatively associated with employment in some specifications, though their empirical magnitudes are zero or very small in the full specifications. The variable that indicates corporate licence fees relative to GDP is also negatively associated with employment, though given the extremely low mean of this variable, its empirical magnitude is also very small. ${ }^{8}$

Increasing licence fees by $25 \%$ of the mean value for this variable is associated with one-tenth of $1 \%$ lower employment. Personal income tax rates are positively associated with employment. 
Most control variable results are as expected. Economic conditions are associated with employment in the hypothesised direction. When national unemployment rates are high, that is associated with lower employment in states; this variable is dropped from the time-effects specifications due to lack of state-level variation. State-level gross domestic product is positively associated with employment.

Several variables are used to capture structural features of the economy. In equations (2) and (5), higher gross state product (GSP) per capita states also have higher employment. In equations (3) and (6), the estimated coefficient on this variable changes sign, but several other control variables are introduced, including the share of the population with a college degree (positively associated with employment in equation 6), the ratio of workers that are in manufacturing (positively associated with employment levels), and the share of young (18 and under) and old (65 and over) in the population, both of which are negatively associated with employment.

Appendix 2 shows the same specifications without fixed effects. These results are not included in the text throughout the paper, since statistical tests overwhelming indicate that fixed state effects are required. Further, the exclusion of state fixed effects risks biasing the coefficients due to spurious correlations between tax policy variables and other features of a state. The inclusion of fixed effects has an important effect on the results, as Appendix 2 indicates. $^{9}$

\subsection{Investment activity}

Table 3 considers how tax policy variables affect investment across US states, using data on capital expenditure from the Annual Survey of Manufacturers. Again, fixed state effects are necessary, and columns (1) to (3) show fixed state effects, while columns (4) to (6) include both state and year fixed effects.

For comparison, Table A1 shows regular pooled regressions (specifications 1-3) and regressions with region fixed effects (specifications 4-6), following the region designations of Crone (2005). These specifications show a large and negative statistically significant effect of the payroll tax burden, although the effect gets smaller when the full set of controls are included. In specification (6), a standard deviation increase in the payroll tax burden (equal to $50 \%$ of the mean burden) would reduce employment by $0.6 \%$. The control variables are broadly consistent with results in the main specifications, though throwback rules and combined reporting requirements are sometimes positively associated with employment. The mid-Atlantic states are the omitted region; other regions typically have higher employment in the full specification, reported in column 6. 
Table 3 Capital expenditure regressions, state fixed effects (1-3), state and year fixed effects (4-6)

Dependent variable: Ln of capital expenditure

\begin{tabular}{|c|c|c|c|c|c|c|}
\hline & (1) & $(2)$ & (3) & (4) & $(5)$ & $(6)$ \\
\hline assetbur & $\begin{array}{l}-16.04^{*} \\
(1.641)\end{array}$ & $\begin{array}{c}5.575^{*} \\
(1.707)\end{array}$ & $\begin{array}{c}4.640^{*} \\
(1.652)\end{array}$ & $\begin{array}{c}4.966^{*} \\
(1.521)\end{array}$ & $\begin{array}{c}6.078^{*} \\
(1.511)\end{array}$ & $\begin{array}{c}4.567^{*} \\
(1.517)\end{array}$ \\
\hline unem & $\begin{array}{l}-6.235^{\star} \\
(0.566)\end{array}$ & $\begin{array}{l}-5.821^{*} \\
(0.479)\end{array}$ & $\begin{array}{l}-3.809^{\star} \\
(0.551)\end{array}$ & $\begin{array}{l}-6.358^{\star} \\
(0.736)\end{array}$ & $\begin{array}{l}-4.262^{*} \\
(0.817)\end{array}$ & $\begin{array}{l}-2.713^{\star} \\
(0.887)\end{array}$ \\
\hline throwback & & $\begin{array}{c}0.0407 \\
(0.0409)\end{array}$ & $\begin{array}{c}0.0844^{*} \\
(0.0393)\end{array}$ & & $\begin{array}{c}-0.0148 \\
(0.0366)\end{array}$ & $\begin{array}{c}0.0351 \\
(0.0367)\end{array}$ \\
\hline combrep & & $\begin{array}{r}-0.00321 \\
(0.0210)\end{array}$ & $\begin{array}{c}0.0189 \\
(0.0208)\end{array}$ & & $\begin{array}{l}-0.0315 \\
(0.0190)\end{array}$ & $\begin{array}{c}0.00504 \\
(0.0195)\end{array}$ \\
\hline Ingsppc & & $\begin{array}{c}0.682^{*} \\
(0.0319)\end{array}$ & $\begin{array}{c}0.539^{*} \\
(0.221)\end{array}$ & & $\begin{array}{c}1.290^{*} \\
(0.178)\end{array}$ & $\begin{array}{c}0.149 \\
(0.251)\end{array}$ \\
\hline pitax & & & $\begin{array}{c}0.150 \\
(0.884)\end{array}$ & & & $\begin{array}{c}-1.839^{*} \\
(0.836)\end{array}$ \\
\hline licgsp & & & $\begin{array}{c}28.00 \\
(25.71)\end{array}$ & & & $\begin{array}{c}-19.76 \\
(23.83)\end{array}$ \\
\hline Ingsp & & & $\begin{array}{c}0.704^{*} \\
(0.155)\end{array}$ & & & $\begin{array}{c}0.604^{*} \\
(0.144)\end{array}$ \\
\hline ba & & & $\begin{array}{c}-0.0194^{*} \\
(0.00600)\end{array}$ & & & $\begin{array}{c}-0.0203^{*} \\
(0.00636)\end{array}$ \\
\hline manufratio & & & $\begin{array}{c}7.365^{*} \\
(0.724)\end{array}$ & & & $\begin{array}{c}4.731^{*} \\
(0.802)\end{array}$ \\
\hline youngshare & & & $\begin{array}{c}3.544^{*} \\
(1.101)\end{array}$ & & & $\begin{array}{l}-1.480 \\
(1.126)\end{array}$ \\
\hline oldshare & & & $\begin{array}{c}7.959^{*} \\
(1.730)\end{array}$ & & & $\begin{array}{l}-3.978^{*} \\
(1.940)\end{array}$ \\
\hline Fixed effects? & yes & yes & yes & yes & yes & yes \\
\hline Year effects? & no & no & no & yes & yes & yes \\
\hline$N$ & 1084 & 1064 & 998 & 1084 & 1064 & 998 \\
\hline$R^{2}$ & 0.149 & 0.417 & 0.503 & 0.540 & 0.561 & 0.601 \\
\hline
\end{tabular}

Standard errors in parentheses $p<0.05$

The main tax policy variable of interest is the measure of tax burden on assets, the multiple of the corporate tax rate and the weight on assets in the formula allocation. In the first specification, without additional controls, there is a statistically significantly negative relation between this tax burden and capital expenditure; however, all other empirical models shown in columns (2) to (6) show unexpectedly positive relationships between asset tax burdens and capital expenditure, even after a full set of control variables is included. Other tax policy measures (the throwback rule, required combined reporting, the personal income tax, and corporate licence fees) are typically statistically insignificant, with the exception of one positive effect of throwback rules in column (3) and one negative effect of personal income taxes in column (6).

Economic control variables have the expected associations with capital expenditure, with statewide unemployment associated with lower capital expenditure and increased GSP associated with increased capital expenditure. Structural control variables indicate a positive relationship between GSP per capita and investment, and between the manufacturing ratio in the economy 
and investment. There is a negative relationship between the share of the population with a college degree and investment, and demographic variables have mixed effects. Again, Appendix Table A2 reports ordinary pooled regressions as well as pooled regressions with region-specific effects. ${ }^{10}$

\subsection{Sales activity}

Table 4 reports regressions on sales across US states, following similar specification choices as above. Columns 1-3 report state fixed effects, and columns 4-6 report specifications with both state and year fixed effects. An additional policy variable is considered here, the interaction between the sales burden and the throwback rule dummy variable. This is intended to capture the fact that sales burdens will be more burdensome if states are also taxing income that is earned in another state. According to the Uniform Division of Income for Tax Purposes Act (UDITPA), sales may be 'thrown back' to the state from which the sales are shipped if the seller is not taxable in the destination state or if the buyer is the US government. 
Table 4 Sales regressions, state fixed effects (1-3), state and year fixed effects (4-6)

Dependent variable: Ln of sales

\begin{tabular}{|c|c|c|c|c|c|c|}
\hline & (1) & (2) & (3) & (4) & (5) & (6) \\
\hline salesburden & $\begin{array}{c}9.556^{*} \\
(0.726)\end{array}$ & $\begin{array}{l}0.0364 \\
(0.526)\end{array}$ & $\begin{array}{c}-0.0885 \\
(0.487)\end{array}$ & $\begin{array}{l}-0.255 \\
(0.414)\end{array}$ & $\begin{array}{l}0.0125 \\
(0.483)\end{array}$ & $\begin{array}{c}-0.0847 \\
(0.465)\end{array}$ \\
\hline unem & $\begin{array}{l}-2.222^{*} \\
(0.495)\end{array}$ & $\begin{array}{l}-2.109^{*} \\
(0.252)\end{array}$ & $\begin{array}{l}-0.888^{\star} \\
(0.258)\end{array}$ & $\begin{array}{l}-4.406^{*} \\
(0.445)\end{array}$ & $\begin{array}{l}-1.561^{*} \\
(0.451)\end{array}$ & $\begin{array}{c}0.764 \\
(0.435)\end{array}$ \\
\hline throwback & & $\begin{array}{l}-0.0220 \\
(0.0327)\end{array}$ & $\begin{array}{l}-0.0145 \\
(0.0285)\end{array}$ & & $\begin{array}{l}-0.0626^{*} \\
(0.0308)\end{array}$ & $\begin{array}{l}-0.0342 \\
(0.0277)\end{array}$ \\
\hline throwsb & & $\begin{array}{l}-0.493 \\
(0.637)\end{array}$ & $\begin{array}{c}-0.209 \\
(0.554)\end{array}$ & & $\begin{array}{c}-0.300 \\
(0.593)\end{array}$ & $\begin{array}{l}-0.402 \\
(0.532)\end{array}$ \\
\hline combrep & & $\begin{array}{r}-0.00710 \\
(0.0111)\end{array}$ & $\begin{array}{c}0.00766 \\
(0.00976)\end{array}$ & & $\begin{array}{l}-0.0187 \\
(0.0105)\end{array}$ & $\begin{array}{c}0.00651 \\
(0.00949)\end{array}$ \\
\hline Ingsppc & & $\begin{array}{c}0.818^{*} \\
(0.0152)\end{array}$ & $\begin{array}{c}0.793^{*} \\
(0.103)\end{array}$ & & $\begin{array}{c}1.481^{\star} \\
(0.0987)\end{array}$ & $\begin{array}{c}0.803^{\star} \\
(0.122)\end{array}$ \\
\hline pitax & & & $\begin{array}{l}-0.485 \\
(0.428)\end{array}$ & & & $\begin{array}{l}-1.219^{*} \\
(0.421)\end{array}$ \\
\hline licgsp & & & $\begin{array}{l}-47.84^{\star} \\
(12.73)\end{array}$ & & & $\begin{array}{l}-66.11^{\star} \\
(12.26)\end{array}$ \\
\hline Ingsp & & & $\begin{array}{c}0.403^{*} \\
(0.0727)\end{array}$ & & & $\begin{array}{c}0.387^{\star} \\
(0.0701)\end{array}$ \\
\hline ba & & & $\begin{array}{c}-0.0281^{\star} \\
(0.00283)\end{array}$ & & & $\begin{array}{c}-0.0244^{\star} \\
(0.00314)\end{array}$ \\
\hline manufratio & & & $\begin{array}{l}4.161^{\star} \\
(0.342)\end{array}$ & & & $\begin{array}{c}3.246^{*} \\
(0.393)\end{array}$ \\
\hline youngshare & & & $\begin{array}{l}-1.448^{\star} \\
(0.515)\end{array}$ & & & $\begin{array}{l}-3.394^{*} \\
(0.547)\end{array}$ \\
\hline oldshare & & & $\begin{array}{c}4.162^{*} \\
(0.813)\end{array}$ & & & $\begin{array}{c}1.249 \\
(0.947)\end{array}$ \\
\hline Fixed effects? & yes & yes & yes & yes & yes & yes \\
\hline Year effects? & no & no & no & yes & yes & yes \\
\hline$N$ & 1084 & 1064 & 998 & 1084 & 1064 & 998 \\
\hline$R^{2}$ & 0.146 & 0.787 & 0.858 & 0.782 & 0.825 & 0.877 \\
\hline
\end{tabular}

Standard errors in parentheses ${ }^{*} p<0.05$

In most specifications, the sales burden variable is statistically insignificant, and the only exception is an anomalous positive sign in equation (1). Throwback rules have a negative effect on sales in equation (5) but are otherwise statistically insignificant. The throwback/sales burden interaction term always has a negative sign, but it is never statistically significant.

Control variables are typically as expected. Lower unemployment or higher GSP increase sales, and states with higher per capita GSP and manufacturing ratios tend to have higher sales. Corporate licence fees have a negative association with sales; in equation (6), an increase in licence fees of 25 per cent of the mean value for this variable reduces sales by 1.1 per cent. 
Although fixed state effects are clearly indicated, Appendix Table A3 shows the results for pooled and region effects specifications for reference. ${ }^{11}$

\subsection{Discussion of activity results}

The above results indicate very few negative tax burden effects on employment, investment, or sales. What is one to make of this finding? First, it may simply be the case that at low tax rates, economic activity is not that responsive to the tax burdens associated with formulary apportionment. Employment and investment decisions may be determined by more important considerations, and sales are determined by where customers are. While it is likely to be the case that real economic activity is more responsive to tax burdens at higher tax rates, it is also the case that employment and investment mobility is probably far easier (i.e., more footloose) within countries than between countries. The former consideration implies that tax responses would be larger in the international context, whereas the latter consideration implies smaller tax responses.

Second, it should be noted that this work contrasts with some, but not all, prior work on US states. Goolsbee and Maydew (2000) find that employment is responsive to tax burden differences across states; Gupta and Hofmann (2003) find small capital expenditure responses in some specifications; and Klassen and Shackelford (1998) find that sales are sensitive to tax burdens in throwback states. However, as noted earlier, these studies all employ data that ends by the mid-1990s. Also, some specifications do not include adequate controls, such as statespecific effects.

Therefore, I also analysed subsamples of the data focusing on the early and later time periods. There are reasons to expect that tax responsiveness could change over time. For example, one hypothesis is that first-mover states (that increased the sales factor weights during a period when other states were largely using the traditional formula) would have gained a larger competitive advantage vis à vis other states in comparison to late-mover states (that changed their formulas in a context where many other states had already adopted formulas with disproportionately heavy sales weights).

There are some important changes in the results when the sample is limited to early years (ending in 1995). For the analysis of employment, there are more negative and/or statistically significant effects of payroll tax burdens. For the capital expenditure analysis regressions, the asset tax burden loses its (perversely) positive effect on investment, and it instead becomes statistically indistinguishable from zero. For the sales regressions, there are some negative tax effects for throwback states. These results offer some limited support for the first-mover hypothesis above, where states that alter formulas first are more likely to gain at the expense of other states before tax competition becomes pervasive.

\subsection{Government corporate tax revenue}

This time period has experienced a large increase in the importance of corporate profits. Figure 2 shows corporate profits as a share of GDP for the US as a whole (left axis), as well as US state and local corporate tax revenues relative to GDP (right axis). Over the past quarter century, corporate profits have increased from 7 per cent of GDP to over 12 per cent of GDP;

Here, tax effects are typically minimal. There is no negative effect associated with corporate licence fees or sales corporate tax burdens. In one case (column 2), throwback rules have a negative effect, and in one case (column 3 ) the interaction between the sales burden and the throwback rule has a negative effect. 
though they fluctuate with the cyclical position of the economy, there is a clear upward trend. State and local corporate tax revenues also fluctuate with the state of the economy, but there is a small downward trend over this time period.

\section{Figure 2 Corporate profits and state corporate tax revenues as a share of GDP}

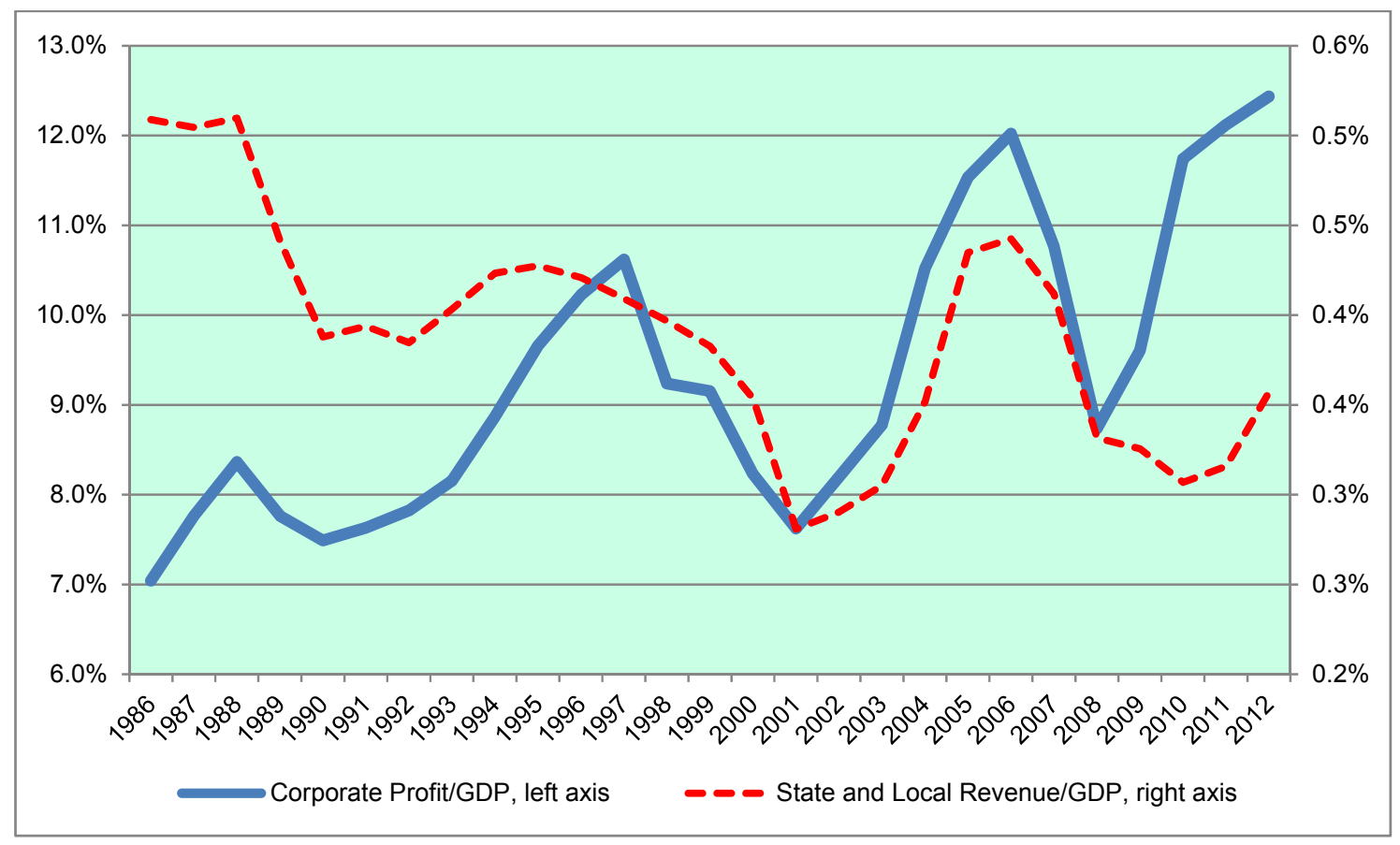

Note: Data is from the Bureau of Economic Analysis (BEA) as reported in the 2013 Economic Report of the President. 2012 data is preliminary; revenue data for 2012 is from the BEA and the Office of Management and Budget.

Table 5 reports regressions considering determinants of state government corporate tax revenues as a share of GSP; columns (1) to (3) include state fixed effects and columns (4) to (6) include state and year fixed effects. Policy choices have important effects on revenue. Tax rates are positively and statistically significantly associated with revenues in all specifications. A tax rate one percentage point higher is typically associated with a share of corporate tax revenue in GSP that is about 5 per cent higher. ${ }^{12}$

. to GSP by about .0164 . The mean corporate tax revenue to GSP ratio is 0.34 , so the revenue to GSP ratio increases by $4.8 \%$. 
Table 5 Corporate state income tax revenue/GSP regressions, state fixed effects (1-3), state and year fixed effects (4-6)

\begin{tabular}{|c|c|c|c|c|c|c|}
\hline & $(1)$ & (2) & (3) & (4) & (5) & (6) \\
\hline \multirow[t]{2}{*}{ rate } & \multirow{2}{*}{$\begin{array}{c}1.648^{*} \\
(0.298)\end{array}$} & \multirow{2}{*}{$\begin{array}{l}1.622^{*} \\
(0.332)\end{array}$} & \multirow{2}{*}{$\begin{array}{c}1.494^{*} \\
(0.336)\end{array}$} & $1.591^{*}$ & $1.799^{*}$ & $1.710^{*}$ \\
\hline & & & & $(0.264)$ & $(0.292)$ & $(0.293)$ \\
\hline \multirow[t]{2}{*}{ salesw } & \multirow{2}{*}{$\begin{array}{c}-0.133^{*} \\
(0.0199)\end{array}$} & \multirow{2}{*}{$\begin{array}{l}-0.0426 \\
(0.0266)\end{array}$} & \multirow{2}{*}{$\begin{array}{l}-0.0334 \\
(0.0266)\end{array}$} & $-0.0510^{*}$ & $-0.0627^{\star}$ & $-0.0524^{\star}$ \\
\hline & & & & $(0.0215)$ & $(0.0234)$ & $(0.0232)$ \\
\hline \multirow[t]{2}{*}{ unem } & \multirow{2}{*}{$\begin{array}{l}-1.553^{*} \\
(0.173)\end{array}$} & \multirow{2}{*}{$\begin{array}{l}-1.355^{\star} \\
(0.184)\end{array}$} & \multirow{2}{*}{$\begin{array}{l}-1.446^{*} \\
(0.186)\end{array}$} & $-2.527^{*}$ & $-1.934^{*}$ & $-2.310^{*}$ \\
\hline & & & & $(0.255)$ & $(0.312)$ & $(0.317)$ \\
\hline \multirow[t]{2}{*}{ Inosurplus } & & \multirow{2}{*}{$\begin{array}{c}0.0724^{*} \\
(0.0274)\end{array}$} & \multirow{2}{*}{$\begin{array}{c}0.0592^{*} \\
(0.0279)\end{array}$} & & 0.0122 & -0.0177 \\
\hline & & & & & $(0.0295)$ & $(0.0299)$ \\
\hline \multirow[t]{2}{*}{ share } & & \multirow{2}{*}{$\begin{array}{l}-0.393^{*} \\
(0.116)\end{array}$} & \multirow{2}{*}{$\begin{array}{l}-0.337^{*} \\
(0.118)\end{array}$} & & $-0.420^{*}$ & $-0.388^{*}$ \\
\hline & & & & & $(0.168)$ & $(0.171)$ \\
\hline \multirow[t]{2}{*}{ throwback } & & & \multirow{2}{*}{$\begin{array}{c}0.0620^{*} \\
(0.0162)\end{array}$} & & & $0.0456^{*}$ \\
\hline & & & & & & $(0.0142)$ \\
\hline \multirow[t]{2}{*}{ combrep } & & & \multirow{2}{*}{$\begin{array}{c}-0.00894 \\
(0.00802)\end{array}$} & & & $-0.0258^{*}$ \\
\hline & & & & & & $(0.00733)$ \\
\hline \multirow[t]{2}{*}{ forchoice } & & & \multirow{2}{*}{$\begin{array}{l}0.00347 \\
(0.0138)\end{array}$} & & & 0.00466 \\
\hline & & & & & & $(0.0122)$ \\
\hline \multirow[t]{2}{*}{ crchoice } & & & \multirow{2}{*}{$\begin{array}{l}-0.00784 \\
(0.00902)\end{array}$} & & & $-0.0215^{\star}$ \\
\hline & & & & & & $(0.00910)$ \\
\hline Fixed effects? & yes & yes & yes & yes & yes & yes \\
\hline Year effects? & no & no & no & yes & yes & yes \\
\hline$N$ & 1122 & 959 & 947 & 1122 & 959 & 947 \\
\hline$R^{2}$ & 0.147 & 0.144 & 0.162 & 0.390 & 0.364 & 0.388 \\
\hline
\end{tabular}

Standard errors in parentheses

$p<0.05$

Higher sales weights lower revenues in equations (1), (4), (5), and (6) with 95 per cent confidence, in equation (2) with 89 per cent confidence, and always have a negative sign. Taking the average sales weight coefficient from this table, this implies that moving from an equal-weighted formula to one that double-weights sales will be associated with a share of corporate tax revenue in GSP that is about 2.5 per cent lower. ${ }^{13}$ States with throwback rules have higher revenues, and other tax policy variables often have statistically insignificant coefficients.

Control variables are as expected. Higher state unemployment is associated with lower corporate tax revenues; higher corporate profits, measured by operating surplus, are associated with higher revenues. As the share of business returns that are pass-through entities increases, corporate tax revenues decrease. As above, Appendix Table A4 reports results from pooled and region-effect specifications. ${ }^{14}$

\footnotetext{
13 The average sales weight coefficient in this table is -0.0498 , including the two statistically insignificant results as 0 . A sales weight 17 percentage points higher decreases the ratio of tax revenue to GSP by about $.17^{*}-0.0498$, or -.0084 . The mean corporate tax revenue to GSP ratio is . 34 . So the revenue to GSP ratio decreases by $2.5 \%$.

14 In these results, tax rates continue to be positively associated with revenues, and sales weights continue to be negatively associated with revenues, with a more sizeable negative impact. Both throwback rules and required combined reporting are associated with higher revenues.
} 


\subsection{Extensions}

Several extensions and robustness checks were considered. Results are summarised briefly here but all tables are available from the author upon request. First, as noted above, subsamples of the data set focusing on the early and later time periods were analysed. Indeed, there are some important changes in the results when the sample is limited to early years (ending in 1995). As noted above, activity, and especially employment, appears to be more negatively related to tax burdens in the early time period. In addition, in the revenue regressions, in both pooled and fixed effects specifications, the sales weight term no longer has a negative effect on tax revenues when the sample is restricted to early years. One plausible explanation for this set of findings is that, as tax competition became more pervasive, it resulted in far lower 'bang for the buck' for states raising their formula sales weights in an attempt to encourage job creation and investment in their home state. Positive effects on jobs and investments disappeared, and, instead, states simply lost corporate tax revenue.

Second, all of the above analyses were done on specifications that deliberately excluded Alaska, Hawaii and the District of Columbia, as is the tradition in much state-level empirical research. Still, all results were checked without this exclusion, and this exclusion does not affect any of the main policy conclusions.

Third, I included alternate measures of the dependent variables, when possible. For employment, there are other BEA series that show non-farm, private payroll and manufacturing employment. There are also measures from surveys of foreign multinational firms with US affiliates that show employment and manufacturing employment. Finally, a measure of labour force participation can be constructed by taking the ratio of the labour force to the working age population. In most cases the tax policy results were broadly similar. The one exception was labour force participation, which showed a persistent negative relationship to payroll burdens in fixed effects specifications.

For capital expenditure, one may also consider a series on property, plant and equipment investments by foreign multinational firms; like capital expenditure, these were not negatively related to asset burdens in the fixed effects specifications. For sales, the Census reports a retail sales figure every five years. While this entails fewer observations than the Annual Survey of Manufacturers' sales data, the tax policy variable results were similar.

\subsection{Policy endogeneity concerns}

Studies on the consequences of tax policy are often plagued by concerns of endogenous relationships between policy parameters and dependent variables. For example, if state policymakers choose sales weights and tax rates with the hope of improving disappointing economic conditions, we may find a negative relationship between employment and lower sales weights due to that policy impetus, even if the lower sales weight eventually boosts employment. Or, perhaps some policy environments are inherently more business-friendly, and in these environments states adopt lower tax rates and payroll/asset weights in their formulas but also undertake myriad other policy changes that also affect underlying economic fundamentals. In both cases, we would be concerned of biased results, although the nature of the bias is in the opposite direction in these two examples.

In several respects, the above analyses are responsive to these concerns. For example, variables are typically included that reflect the underlying economic conditions of the state (GSP, unemployment, etc.). Also, the key tables in the text all include state-specific fixed effects, which 
should address some of the business climate concerns. Many specifications also include year effects that should capture macroeconomic shocks as well as other time-specific phenomena.

However, it is also useful to examine possible determinants of policy changes. Therefore, I examined two probit analyses, considering the determinants of state decisions to increase the sales weight in their apportionment formulas (Appendix Table A5), or to lower corporate tax rates (Appendix Table A6). Over the entire sample, in 8 per cent of observations states increase the sales weight in their apportionment formulas, and in 3 per cent of observations states lower their corporate tax rate by at least nine-tenths of one percentage point. (Occasionally, states undertake very mild or gradual rate reductions, and I exclude these instances from the analysis.)

Tables A5 and A6 both show specifications that include more independent variables as you move rightwards across the table. The baseline specification (column 1) models the policy change as depending on the mean policy of other states, the state unemployment rate, Republican control over both legislative and executive branches of state government, Democratic control over both branches (with the omitted category being split control), and whether it is an election year. Column 2 also includes other tax policies and state GSP per capita; column 3 includes the debt/GSP and federal aid/GSP ratios for states as well as the share of the population that is young (18 and under) or old (65 and older); and column 4 includes lags of prior values for other states' policies, tax rates, GSP, unemployment, and political outcomes.

The remarkable feature of the probit regressions is how few statistically significant determinants of policy changes are apparent in the results. Across four sales weight specifications, the only variable that is associated with higher sales weights is the mean weight in other states (in two columns) and the lag of the mean rate of the sales weight in other states (in column four). Across four tax rate change specifications, there is only one statistically significant coefficient, the mean tax rate in other states (in equation 4 only). These results provide substantial evidence that tax policy changes are not explained well by seemingly plausible observable variables, thus reducing possible policy endogeneity concerns.

\section{Conclusions and policy implications}

US states have a long experience with the formulary apportionment of corporate income. In comparison to separate accounting, formulary apportionment substantially reduces concerns regarding the shifting of income from high-tax to low-tax states. Corporate tax liabilities are based on national income and the factors in the formula, factors that reflect underlying economic activity. Indeed, Mintz and Smart (2004) provide evidence of reduced income shifting under formulary apportionment.

Under separate accounting, firms have more flexibility in how they account for where income is earned, and a long body of empirical research demonstrates that corporations are eager to reduce their tax liabilities by utilising such flexibility. Indeed, due to tax-motivated transfer pricing and income shifting, the booking of global income is quite sensitive to tax rate differences across countries. ${ }^{15}$

Still, this does not mean that tax competition disappears under formulary apportionment. Indeed,

15 See De Mooij (2005) and De Mooij and Ederveen (2008) for reviews. 
it has long been recognised that firms face tax incentives to distort the location of formula factors in order to reduce their tax burdens. In US states, policymakers have responded to business lobbying by systematically lowering the weight on assets and payroll in their apportionment formulas, and raising the sales weight, in an attempt to lure tax-sensitive jobs and investments to their states. In 1986, the beginning of this study, 80 per cent of states used an equal-weighted formula; by 2012 only 17 per cent of states that taxed corporate income had an equal-weighted formula, choosing instead formulas with higher weights on sales.

There is evidence, particularly in Goolsbee and Maydew (2000), that state policymakers were initially successful in attracting jobs from other states with such strategies, although evidence indicates that these policies were 'beggar thy neighbour', since states that gained employment did so at the expense of other states. However, in the time period of this study, 1986 to 2012, there is scant evidence that state employment, investment, or sales are sensitive to corporate tax policy parameters, once an adequate set of control variables are included in the analysis. These findings suggest some cautious optimism for advocates of international formulary apportionment. Formulary apportionment has the potential to reduce income-shifting incentives without generating accompanying large tax responses in economic activity such as employment and investment.

It is important to note that tax rates in US states are typically lower than those found at the national level, so tax responsiveness of real activity may be higher internationally, in the presence of higher tax rates. On the other hand, tax competition is also likely to be fiercer within countries than between countries, due to the greater mobility of capital and labour, easier corporate relocation, and more intense product price competition due to seamless goods mobility, more perfect information, and the absence of exchange rate fluctuations.

The absence of economic activity responses to tax burdens under formulary apportionment in this analysis of US states may also be related to the extended time period of this study. While early states that changed formulas may have gained employment at the expense of other states, as more states changed their formulas, the relative competitive advantage diminished. This suggests that the dynamics of tax competition under formulary apportionment are likely to change over time. If countries have the flexibility to adopt distinct formulas, there may be a temptation to pursue beggar-my-neighbour policy choices in an attempt to lure economic activity from other jurisdictions, but if these strategies are adopted by many jurisdictions they may prove ineffective over time.

The analysis also provides evidence that tax competition pressures are harmful to government revenues, as findings indicate that tax revenues are sensitive to tax policy choices regarding tax rates, sales weights, and throwback rules. This particular finding suggests that international coordination to choose harmonised formulas - and to harmonise other aspects of tax base definition - is particularly desirable. Not only would this reduce the potential for double taxation (and double non-taxation), it would also reduce beggar-my-neighbour policy choices that are ultimately likely to generate tax base erosion. 


\section{Appendices}

\section{Appendix 1 Data sources}

In general, data was collected for the fifty states as well as the District of Columbia over the period 1986-2012, although in most reported regression analyses some states were excluded, as described in the text.

Data on US state corporate tax policies, including both tax rates and various rules, comes from several sources. These include The Book of the States by the Council of State Governments (1986 to 2001), Significant Features of Fiscal Federalism (1986 to 1994) by the Advisory Commission on Intergovernmental Relations, and the Commerce Clearing House publications The Multistate Corporate Tax Almanac (1986-1989), the Multistate Corporate Tax Guide (19952000), the State Tax Handbook (2001-2008) and the US Master Multistate Corporate Tax Guide (2006-2013).

Data on the share of corporate returns that are pass-through organisations is from a special tabulation from the IRS, based on data reported in Publication 6149. This variable is defined as the number of returns filed by partnerships and $\mathrm{S}$ corporations relative to the total number of corporate tax returns. ${ }^{16}$

Data on employment is from the US Bureau of Economic Analysis [BEA]. For manufacturing employment, data for 1986 to 1990 is based on SIC industry codes, and data for 1990-2012 is based on NAICS codes. For manufacturing, the 1990 ratio of SIC to NAICS manufacturing data is used to adjust the late 1980 s data to NAICS equivalents.

The BEA also provides data on total income, earnings, wages, corporate gross operating surplus, and GSP. The GSP series are also affected by the change from SIC to NAICS codes, so the late 1980 s data is similarly adjusted.

The BEA provides data on foreign direct investment into US states, including the gross property, plant and equipment of affiliates, the number of affiliates, the employment of affiliates, and the manufacturing employment of affiliates. For the period 1986-2006, data is for all non-bank affiliates. Data for 2007 to 2010 is not strictly comparable since they also include banks, but this data is adjusted to be comparable by using data on ratios of comparable series.

Data from the Annual Survey of Manufacturers is collected from several sources of the US Census Bureau including CDs (1987-91), publications on the Annual Survey of Manufacturers (1992-96), web pages (2002-11), and an Excel spreadsheet emailed from a Census Bureau employee (1997-2001). This data includes information on manufacturing employment, payroll, materials costs, shipments, value added, and capital expenditure.

The US Census Bureau was the source of data on corporate tax revenues, corporate licence fees, state populations, and the share of the population with a bachelor's degree or higher. For the bachelor's degree share data, data has been input for the years 1986-89 based on an

16 S corporations are corporations that pass corporate income, losses, deductions, and credits through to their shareholders for federal tax purposes. 
average of the growth rates in this share between the years 1980 and 1990 and the years 1990 and 1998. For the years 1991 to 1997, data has been input based on the growth rate over the period 1990-98. Missing data for 2001 is based on an average of 2000 and 2002, and data for 2012 is extrapolated based on 2011 data and the growth rate for the prior year.

The US Bureau of Labor Statistics gives data on the unemployment rate and the labour force.

Data on political control variables comes from the online database of Klarner Politics. See $<$ http://www.indstate.edu/polisci/klarnerpolitics.htm>.

Data on individual income tax rates was based on the top bracket. Data is from The Book of the States by the Council of State Governments in most years, though some years were not available. For the years 1987, 1989, 1991, 1993, rates came from Significant Features of Fiscal Federalism by the Advisory Commission on Intergovernmental Relations; for 1999, the State Tax Handbook by the Commerce Clearing House; for 2001 and 2013, the Tax Policy Center; and for 2012, the Tax Foundation. Missing data was interpolated in cases where the tax rate in prior and subsequent years was the same. For states where tax due is a fraction of the federal liability, the tax rate was imputed based on the federal top rate in the same year.

Data on state election years, the age distribution of the state population, federal aid to the states, and state debt levels was generously shared from a dataset of Jon Rork. The original sources of this data were the US Statistical Abstract (for election years), the US Census (for age distribution and federal aid), and State Government Finances (for debt).

Further information about the details of data acquisition and more detailed variable definitions are available from the author upon request. 
Appendix 2 Results for pooled (OLS) and region effects specifications

Table A1 Employment regressions, pooled estimates (1-3) and region effects (4-6)

\begin{tabular}{|c|c|c|c|c|c|c|}
\hline & (1) & (2) & (3) & (4) & (5) & (6) \\
\hline payburden & $\begin{array}{l}-39.74^{\star} \\
(2.963)\end{array}$ & $\begin{array}{l}-31.84^{*} \\
(3.031)\end{array}$ & $\begin{array}{l}-1.602^{*} \\
(0.252)\end{array}$ & $\begin{array}{l}-27.61^{*} \\
(2.774)\end{array}$ & $\begin{array}{l}-16.00^{*} \\
(3.039)\end{array}$ & $\begin{array}{l}-0.685^{*} \\
(0.216)\end{array}$ \\
\hline natlunem & $\begin{array}{l}-3.224 \\
(1.757)\end{array}$ & $\begin{array}{l}-3.190 \\
(1.693)\end{array}$ & $\begin{array}{l}-1.330^{\star} \\
(0.126)\end{array}$ & $\begin{array}{l}-2.255 \\
(1.422)\end{array}$ & $\begin{array}{l}-2.487 \\
(1.393)\end{array}$ & $\begin{array}{c}-1.155^{*} \\
(0.0984)\end{array}$ \\
\hline throwback & & $\begin{array}{c}-0.390^{*} \\
(0.0525)\end{array}$ & $\begin{array}{c}0.0165^{*} \\
(0.00417)\end{array}$ & & $\begin{array}{c}-0.114^{\star} \\
(0.0505)\end{array}$ & $\begin{array}{c}-0.00107 \\
(0.00361)\end{array}$ \\
\hline combrep & & $\begin{array}{c}-0.134^{*} \\
(0.0536)\end{array}$ & $\begin{array}{c}0.0264^{*} \\
(0.00418)\end{array}$ & & $\begin{array}{c}-0.0248 \\
(0.0467)\end{array}$ & $\begin{array}{c}0.0217^{*} \\
(0.00340)\end{array}$ \\
\hline Ingsppc & & $\begin{array}{c}0.343^{*} \\
(0.0772)\end{array}$ & $\begin{array}{c}-0.887^{*} \\
(0.0116)\end{array}$ & & $\begin{array}{c}0.489^{*} \\
(0.0693)\end{array}$ & $\begin{array}{c}-0.933^{\star} \\
(0.00957)\end{array}$ \\
\hline pitax & & & $\begin{array}{c}0.289^{*} \\
(0.0912)\end{array}$ & & & $\begin{array}{c}0.125 \\
(0.0801)\end{array}$ \\
\hline licgsp & & & $\begin{array}{c}0.556 \\
(1.245)\end{array}$ & & & $\begin{array}{c}5.448^{*} \\
(1.130)\end{array}$ \\
\hline Ingsp & & & $\begin{array}{c}0.965^{*} \\
(0.00253)\end{array}$ & & & $\begin{array}{c}0.981^{*} \\
(0.00251)\end{array}$ \\
\hline ba & & & $\begin{array}{c}0.00821^{\star} \\
(0.00063)\end{array}$ & & & $\begin{array}{c}0.0112^{*} \\
(0.00059)\end{array}$ \\
\hline manufratio & & & $\begin{array}{c}0.562^{*} \\
(0.0551)\end{array}$ & & & $\begin{array}{c}1.006^{*} \\
(0.0603)\end{array}$ \\
\hline youngshare & & & $\begin{array}{l}-0.406^{*} \\
(0.137)\end{array}$ & & & $\begin{array}{l}-1.344^{\star} \\
(0.119)\end{array}$ \\
\hline oldshare & & & $\begin{array}{l}0.0826 \\
(0.162)\end{array}$ & & & $\begin{array}{l}-0.495^{*} \\
(0.142)\end{array}$ \\
\hline newe & & & & $\begin{array}{c}-1.168^{*} \\
(0.0828)\end{array}$ & $\begin{array}{c}-1.052^{*} \\
(0.0886)\end{array}$ & $\begin{array}{c}0.0117 \\
(0.00791)\end{array}$ \\
\hline southeast & & & & $\begin{array}{c}-0.307^{*} \\
(0.0765)\end{array}$ & $\begin{array}{c}-0.0639 \\
(0.0809)\end{array}$ & $\begin{array}{c}0.0326^{*} \\
(0.00645)\end{array}$ \\
\hline glake & & & & $\begin{array}{c}-0.183^{*} \\
(0.0831)\end{array}$ & $\begin{array}{c}0.0771 \\
(0.0888)\end{array}$ & $\begin{array}{c}0.0323^{*} \\
(0.00707)\end{array}$ \\
\hline plain & & & & $\begin{array}{c}-0.911^{*} \\
(0.0973)\end{array}$ & $\begin{array}{l}-0.616^{*} \\
(0.104)\end{array}$ & $\begin{array}{c}0.143^{*} \\
(0.00803)\end{array}$ \\
\hline rocky & & & & $\begin{array}{l}-1.724^{*} \\
(0.100)\end{array}$ & $\begin{array}{l}-1.464^{*} \\
(0.112)\end{array}$ & $\begin{array}{c}0.169^{*} \\
(0.00985)\end{array}$ \\
\hline swest & & & & $\begin{array}{c}-0.675^{*} \\
(0.0863)\end{array}$ & $\begin{array}{c}-0.423^{*} \\
(0.0955)\end{array}$ & $\begin{array}{c}0.0841^{*} \\
(0.00819)\end{array}$ \\
\hline west & & & & $\begin{array}{c}0.214^{*} \\
(0.100)\end{array}$ & $\begin{array}{c}0.440^{\star} \\
(0.109)\end{array}$ & $\begin{array}{c}0.0287^{*} \\
(0.00833)\end{array}$ \\
\hline $\begin{array}{l}N \\
R^{2}\end{array}$ & $\begin{array}{l}1122 \\
0.14\end{array}$ & $\begin{array}{l}1102 \\
0.21\end{array}$ & $\begin{array}{l}1032 \\
0.99\end{array}$ & $\begin{array}{l}1122 \\
0.44\end{array}$ & $\begin{array}{l}1102 \\
0.47\end{array}$ & $\begin{array}{l}1032 \\
0.99\end{array}$ \\
\hline
\end{tabular}

Standard errors in parentheses $p<0.05$ 
Table A2 Capital expenditure regressions, pooled (1-3) and region effects (4-6)

\begin{tabular}{|c|c|c|c|c|c|c|}
\hline & (1) & (2) & (3) & (4) & (5) & (6) \\
\hline assetbur & $\begin{array}{l}-46.51^{*} \\
(3.367)\end{array}$ & $\begin{array}{l}-37.58^{*} \\
(3.454)\end{array}$ & $\begin{array}{l}-2.143 \\
(1.323)\end{array}$ & $\begin{array}{l}-29.31^{*} \\
(3.097)\end{array}$ & $\begin{array}{l}-14.28^{*} \\
(3.353)\end{array}$ & $\begin{array}{c}-1.351 \\
(1.447)\end{array}$ \\
\hline unem & $\begin{array}{l}5.260^{*} \\
(1.597)\end{array}$ & $\begin{array}{l}5.195^{\star} \\
(1.538)\end{array}$ & $\begin{array}{l}-2.002^{*} \\
(0.554)\end{array}$ & $\begin{array}{l}-1.698 \\
(1.321)\end{array}$ & $\begin{array}{l}-1.333 \\
(1.274)\end{array}$ & $\begin{array}{l}-2.013^{*} \\
(0.574)\end{array}$ \\
\hline throwback & & $\begin{array}{c}-0.332^{*} \\
(0.0599)\end{array}$ & $\begin{array}{c}0.0730^{*} \\
(0.0222)\end{array}$ & & $\begin{array}{c}-0.0359 \\
(0.0557)\end{array}$ & $\begin{array}{c}0.0172 \\
(0.0243)\end{array}$ \\
\hline combrep & & $\begin{array}{c}-0.291^{*} \\
(0.0605)\end{array}$ & $\begin{array}{r}-0.00407 \\
(0.0218)\end{array}$ & & $\begin{array}{c}-0.127^{\star} \\
(0.0507)\end{array}$ & $\begin{array}{c}-0.0114 \\
(0.0223)\end{array}$ \\
\hline Ingsppc & & $\begin{array}{c}0.431^{*} \\
(0.0912)\end{array}$ & $\begin{array}{c}0.341^{*} \\
(0.0631)\end{array}$ & & $\begin{array}{c}0.709^{*} \\
(0.0792)\end{array}$ & $\begin{array}{c}0.259^{*} \\
(0.0654)\end{array}$ \\
\hline pitax & & & $\begin{array}{l}-0.158 \\
(0.494)\end{array}$ & & & $\begin{array}{l}-0.210 \\
(0.547)\end{array}$ \\
\hline licgsp & & & $\begin{array}{c}-3.379 \\
(6.608)\end{array}$ & & & $\begin{array}{c}8.612 \\
(7.558)\end{array}$ \\
\hline Ingsp & & & $\begin{array}{c}0.889^{*} \\
(0.0140)\end{array}$ & & & $\begin{array}{c}0.902^{*} \\
(0.0172)\end{array}$ \\
\hline ba & & & $\begin{array}{c}-0.0411^{*} \\
(0.00335)\end{array}$ & & & $\begin{array}{c}-0.0377^{*} \\
(0.00395)\end{array}$ \\
\hline manufratio & & & $\begin{array}{l}7.295^{\star} \\
(0.300)\end{array}$ & & & $\begin{array}{l}7.665^{*} \\
(0.421)\end{array}$ \\
\hline youngshare & & & $\begin{array}{l}0.0184 \\
(0.736)\end{array}$ & & & $\begin{array}{l}-1.200 \\
(0.801)\end{array}$ \\
\hline oldshare & & & $\begin{array}{l}-6.843^{*} \\
(0.864)\end{array}$ & & & $\begin{array}{l}-6.594^{*} \\
(0.959)\end{array}$ \\
\hline neweng & & & & $\begin{array}{c}-0.996^{*} \\
(0.0926)\end{array}$ & $\begin{array}{c}-0.885^{*} \\
(0.0979)\end{array}$ & $\begin{array}{c}0.162^{*} \\
(0.0531)\end{array}$ \\
\hline southeast & & & & $\begin{array}{c}0.0288 \\
(0.0856)\end{array}$ & $\begin{array}{c}0.324^{*} \\
(0.0893)\end{array}$ & $\begin{array}{c}0.0755 \\
(0.0433)\end{array}$ \\
\hline glake & & & & $\begin{array}{c}0.329^{*} \\
(0.0929)\end{array}$ & $\begin{array}{c}0.638^{*} \\
(0.0980)\end{array}$ & $\begin{array}{c}0.183^{*} \\
(0.0474)\end{array}$ \\
\hline plain & & & & $\begin{array}{l}-0.762^{*} \\
(0.110)\end{array}$ & $\begin{array}{l}-0.411^{*} \\
(0.117)\end{array}$ & $\begin{array}{c}0.174^{\star} \\
(0.0544)\end{array}$ \\
\hline rocky & & & & $\begin{array}{l}-1.877^{*} \\
(0.112)\end{array}$ & $\begin{array}{l}-1.566^{*} \\
(0.124)\end{array}$ & $\begin{array}{c}0.196^{*} \\
(0.0661)\end{array}$ \\
\hline swest & & & & $\begin{array}{c}-0.463^{*} \\
(0.0960)\end{array}$ & $\begin{array}{l}-0.181 \\
(0.105)\end{array}$ & $\begin{array}{c}0.282^{*} \\
(0.0548)\end{array}$ \\
\hline west & & & & $\begin{array}{c}0.376^{*} \\
(0.113)\end{array}$ & $\begin{array}{l}0.647^{*} \\
(0.120)\end{array}$ & $\begin{array}{c}0.211^{*} \\
(0.0555)\end{array}$ \\
\hline$N$ & 1084 & 1064 & 998 & 1084 & 1064 & 998 \\
\hline$R^{2}$ & 0.17 & 0.23 & 0.92 & 0.48 & 0.52 & 0.92 \\
\hline
\end{tabular}

Standard errors in parentheses $p<0.05$ 
Table A3 Sales regressions, pooled estimates (1-3), with region effects (4-6)

\begin{tabular}{|c|c|c|c|c|c|c|}
\hline & (1) & (2) & (3) & (4) & (5) & (6) \\
\hline salesburden & $\begin{array}{c}10.51^{*} \\
(1.583)\end{array}$ & $\begin{array}{c}0.747 \\
(1.882)\end{array}$ & $\begin{array}{l}3.640^{*} \\
(0.472)\end{array}$ & $\begin{array}{l}9.819^{*} \\
(1.344)\end{array}$ & $\begin{array}{c}1.842 \\
(1.591)\end{array}$ & $\begin{array}{l}1.035^{*} \\
(0.446)\end{array}$ \\
\hline unem & $\begin{array}{c}10.24^{*} \\
(1.718)\end{array}$ & $\begin{array}{c}8.958^{*} \\
(1.593)\end{array}$ & $\begin{array}{l}-0.496 \\
(0.378)\end{array}$ & $\begin{array}{l}2.230 \\
(1.342)\end{array}$ & $\begin{array}{l}2.016 \\
(1.222)\end{array}$ & $\begin{array}{c}0.600 \\
(0.340)\end{array}$ \\
\hline throwback & & $\begin{array}{l}-0.675^{*} \\
(0.136)\end{array}$ & $\begin{array}{c}0.173^{*} \\
(0.0335)\end{array}$ & & $\begin{array}{l}-0.185 \\
(0.113)\end{array}$ & $\begin{array}{l}-0.0194 \\
(0.0318)\end{array}$ \\
\hline throwsb & & $\begin{array}{l}7.182^{*} \\
(3.184)\end{array}$ & $\begin{array}{l}-3.255^{*} \\
(0.732)\end{array}$ & & $\begin{array}{c}3.271 \\
(2.497)\end{array}$ & $\begin{array}{l}0.0937 \\
(0.679)\end{array}$ \\
\hline combrep & & $\begin{array}{c}-0.314^{*} \\
(0.0630)\end{array}$ & $\begin{array}{l}0.00963 \\
(0.0150)\end{array}$ & & $\begin{array}{c}-0.101^{*} \\
(0.0489)\end{array}$ & $\begin{array}{c}0.0194 \\
(0.0134)\end{array}$ \\
\hline Ingsppc & & $\begin{array}{c}0.889^{*} \\
(0.0948)\end{array}$ & $\begin{array}{c}0.629^{*} \\
(0.0418)\end{array}$ & & $\begin{array}{c}1.045^{*} \\
(0.0721)\end{array}$ & $\begin{array}{c}0.471^{*} \\
(0.0388)\end{array}$ \\
\hline pitax & & & $\begin{array}{l}-0.335 \\
(0.344)\end{array}$ & & & $\begin{array}{c}0.503 \\
(0.332)\end{array}$ \\
\hline licgsp & & & $\begin{array}{c}5.658 \\
(4.392)\end{array}$ & & & $\begin{array}{c}19.80^{*} \\
(4.539)\end{array}$ \\
\hline Ingsp & & & $\begin{array}{c}0.920^{*} \\
(0.00971)\end{array}$ & & & $\begin{array}{c}0.938^{*} \\
(0.0104)\end{array}$ \\
\hline ba & & & $\begin{array}{c}-0.0530^{*} \\
(0.00225)\end{array}$ & & & $\begin{array}{c}-0.0405^{*} \\
(0.00241)\end{array}$ \\
\hline manufratio & & & $\begin{array}{l}7.157^{*} \\
(0.208)\end{array}$ & & & $\begin{array}{l}8.123^{*} \\
(0.261)\end{array}$ \\
\hline youngshare & & & $\begin{array}{l}-0.464 \\
(0.519)\end{array}$ & & & $\begin{array}{l}-2.927^{*} \\
(0.482)\end{array}$ \\
\hline oldshare & & & $\begin{array}{l}-5.488^{*} \\
(0.627)\end{array}$ & & & $\begin{array}{l}-5.439^{*} \\
(0.591)\end{array}$ \\
\hline newengland & & & & $\begin{array}{c}-1.230^{*} \\
(0.0945)\end{array}$ & $\begin{array}{c}-1.047^{*} \\
(0.0959)\end{array}$ & $\begin{array}{c}0.0342 \\
(0.0325)\end{array}$ \\
\hline southeast2 & & & & $\begin{array}{c}0.244^{\star} \\
(0.0877)\end{array}$ & $\begin{array}{c}0.468^{*} \\
(0.0819)\end{array}$ & $\begin{array}{c}0.134^{*} \\
(0.0259)\end{array}$ \\
\hline glake2 & & & & $\begin{array}{c}0.431^{\star} \\
(0.0918)\end{array}$ & $\begin{array}{c}0.728^{*} \\
(0.0904)\end{array}$ & $\begin{array}{c}0.182^{*} \\
(0.0280)\end{array}$ \\
\hline plain2 & & & & $\begin{array}{l}-0.373^{*} \\
(0.109)\end{array}$ & $\begin{array}{l}0.0152 \\
(0.111)\end{array}$ & $\begin{array}{c}0.486^{*} \\
(0.0316)\end{array}$ \\
\hline rocky2 & & & & $\begin{array}{l}-2.034^{*} \\
(0.115)\end{array}$ & $\begin{array}{l}-1.607^{*} \\
(0.120)\end{array}$ & $\begin{array}{c}0.258^{*} \\
(0.0397)\end{array}$ \\
\hline swest2 & & & & $\begin{array}{c}-0.312^{*} \\
(0.0980)\end{array}$ & $\begin{array}{c}-0.116 \\
(0.0985)\end{array}$ & $\begin{array}{c}0.349^{*} \\
(0.0330)\end{array}$ \\
\hline west2 & & & & $\begin{array}{c}0.201 \\
(0.115)\end{array}$ & $\begin{array}{c}0.490^{*} \\
(0.117)\end{array}$ & $\begin{array}{c}0.0746^{*} \\
(0.0333)\end{array}$ \\
\hline $\begin{array}{l}N \\
R^{2}\end{array}$ & $\begin{array}{l}1084 \\
0.07\end{array}$ & $\begin{array}{l}1064 \\
0.22\end{array}$ & $\begin{array}{l}998 \\
0.96\end{array}$ & $\begin{array}{l}1084 \\
0.48\end{array}$ & $\begin{array}{l}1064 \\
0.58\end{array}$ & $\begin{array}{l}998 \\
0.97\end{array}$ \\
\hline
\end{tabular}

Standard errors in parentheses $p<0.05$ 
Table A4 Corporate state income tax revenue/GSP regressions, pooled estimates (1-3), with region effects (4-6)

\begin{tabular}{|c|c|c|c|c|c|c|}
\hline & (1) & (2) & (3) & (4) & (5) & (6) \\
\hline rate & $\begin{array}{l}2.267^{*} \\
(0.233)\end{array}$ & $\begin{array}{l}2.209^{*} \\
(0.249)\end{array}$ & $\begin{array}{l}2.095^{*} \\
(0.255)\end{array}$ & $\begin{array}{c}0.824^{*} \\
(0.251)\end{array}$ & $\begin{array}{c}0.916^{*} \\
(0.266)\end{array}$ & $\begin{array}{c}1.221^{*} \\
(0.272)\end{array}$ \\
\hline salesw & $\begin{array}{c}-0.163^{\star} \\
(0.0232)\end{array}$ & $\begin{array}{c}-0.123^{*} \\
(0.0265)\end{array}$ & $\begin{array}{c}-0.124^{*} \\
(0.0264)\end{array}$ & $\begin{array}{c}-0.185^{*} \\
(0.0224)\end{array}$ & $\begin{array}{c}-0.123^{*} \\
(0.0261)\end{array}$ & $\begin{array}{l}-0.0992^{*} \\
(0.0268)\end{array}$ \\
\hline unem & $\begin{array}{l}-0.216 \\
(0.253)\end{array}$ & $\begin{array}{l}-0.0717 \\
(0.267)\end{array}$ & $\begin{array}{l}-0.0568 \\
(0.264)\end{array}$ & $\begin{array}{l}-0.679^{*} \\
(0.233)\end{array}$ & $\begin{array}{l}-0.594^{*} \\
(0.245)\end{array}$ & $\begin{array}{l}-0.654^{*} \\
(0.244)\end{array}$ \\
\hline Inosurplus & & $\begin{array}{c}0.00636 \\
(0.00523)\end{array}$ & $\begin{array}{c}0.0120^{*} \\
(0.00542)\end{array}$ & & $\begin{array}{r}-0.000133 \\
(0.00576)\end{array}$ & $\begin{array}{c}0.00178 \\
(0.00578)\end{array}$ \\
\hline share & & $\begin{array}{c}-0.246^{*} \\
(0.0553)\end{array}$ & $\begin{array}{c}-0.245^{*} \\
(0.0558)\end{array}$ & & $\begin{array}{c}-0.228^{*} \\
(0.0514)\end{array}$ & $\begin{array}{c}-0.256^{*} \\
(0.0526)\end{array}$ \\
\hline throwback & & & $\begin{array}{c}0.0343^{*} \\
(0.0106)\end{array}$ & & & $\begin{array}{c}0.0462^{*} \\
(0.0110)\end{array}$ \\
\hline combrep & & & $\begin{array}{c}0.0237^{*} \\
(0.0105)\end{array}$ & & & $\begin{array}{c}0.0240^{*} \\
(0.00979)\end{array}$ \\
\hline forchoice & & & $\begin{array}{l}-0.0832^{*} \\
(0.0170)\end{array}$ & & & $\begin{array}{r}-0.00559 \\
(0.0168)\end{array}$ \\
\hline crchoice & & & $\begin{array}{c}0.000941 \\
(0.0140)\end{array}$ & & & $\begin{array}{c}-0.00308 \\
(0.0126)\end{array}$ \\
\hline newengland & & & & $\begin{array}{c}-0.00143 \\
(0.0164)\end{array}$ & $\begin{array}{c}-0.00623 \\
(0.0189)\end{array}$ & $\begin{array}{c}-0.0355 \\
(0.0201)\end{array}$ \\
\hline southeast2 & & & & $\begin{array}{c}-0.106^{\star} \\
(0.0161)\end{array}$ & $\begin{array}{l}-0.0949^{*} \\
(0.0169)\end{array}$ & $\begin{array}{l}-0.0959^{*} \\
(0.0170)\end{array}$ \\
\hline glake2 & & & & $\begin{array}{c}0.0554^{*} \\
(0.0164)\end{array}$ & $\begin{array}{c}0.0582^{*} \\
(0.0173)\end{array}$ & $\begin{array}{c}0.0342 \\
(0.0181)\end{array}$ \\
\hline plain2 & & & & $\begin{array}{c}-0.147^{*} \\
(0.0190)\end{array}$ & $\begin{array}{c}-0.147^{\star} \\
(0.0209)\end{array}$ & $\begin{array}{c}-0.181^{*} \\
(0.0220)\end{array}$ \\
\hline rocky2 & & & & $\begin{array}{l}-0.0588^{*} \\
(0.0199)\end{array}$ & $\begin{array}{c}-0.0291 \\
(0.0242)\end{array}$ & $\begin{array}{l}-0.0779 \\
(0.0259)\end{array}$ \\
\hline swest2 & & & & $\begin{array}{c}-0.181^{*} \\
(0.0180)\end{array}$ & $\begin{array}{c}-0.164^{*} \\
(0.0191)\end{array}$ & $\begin{array}{c}-0.188^{*} \\
(0.0207)\end{array}$ \\
\hline west2 & & & & $\begin{array}{c}-0.0219 \\
(0.0200)\end{array}$ & $\begin{array}{l}-0.0207 \\
(0.0207)\end{array}$ & $\begin{array}{l}-0.0603^{*} \\
(0.0228)\end{array}$ \\
\hline$N$ & 1122 & 959 & 947 & 1122 & 959 & 947 \\
\hline$R^{2}$ & 0.11 & 0.13 & 0.17 & 0.31 & 0.33 & 0.35 \\
\hline
\end{tabular}

Standard errors in parentheses $p<0.05$ 
Appendix 3 Policy probit specifications

Table A5 Probit regressions on probability of raising apportionment weight on sales

\begin{tabular}{|c|c|c|c|c|}
\hline & (1) & (2) & (3) & (4) \\
\hline meansalesw & $\begin{array}{c}1.379 \\
(0.708)\end{array}$ & $\begin{array}{c}1.003 \\
(1.540)\end{array}$ & $\begin{array}{l}5.140^{*} \\
(2.547)\end{array}$ & $\begin{array}{c}36.03^{*} \\
(7.131)\end{array}$ \\
\hline unem & $\begin{array}{c}4.880 \\
(3.041)\end{array}$ & $\begin{array}{c}5.546 \\
(3.458)\end{array}$ & $\begin{array}{c}6.022 \\
(3.797)\end{array}$ & $\begin{array}{c}4.504 \\
(7.750)\end{array}$ \\
\hline rep & $\begin{array}{c}0.128 \\
(0.140)\end{array}$ & $\begin{array}{l}0.0777 \\
(0.152)\end{array}$ & $\begin{array}{c}0.00606 \\
(0.167)\end{array}$ & $\begin{array}{c}0.500 \\
(0.301)\end{array}$ \\
\hline dem & $\begin{array}{c}-0.189 \\
(0.145)\end{array}$ & $\begin{array}{l}-0.161 \\
(0.148)\end{array}$ & $\begin{array}{c}-0.177 \\
(0.155)\end{array}$ & $\begin{array}{c}-0.203 \\
(0.270)\end{array}$ \\
\hline elecyr & $\begin{array}{c}0.00486 \\
(0.127)\end{array}$ & $\begin{array}{r}-0.0155 \\
(0.132)\end{array}$ & $\begin{array}{c}-0.00289 \\
(0.135)\end{array}$ & $\begin{array}{l}-0.206 \\
(0.167)\end{array}$ \\
\hline Ingsppc & & $\begin{array}{c}0.122 \\
(0.370)\end{array}$ & $\begin{array}{c}-0.677 \\
(0.596)\end{array}$ & $\begin{array}{c}-0.856 \\
(0.809)\end{array}$ \\
\hline rate & & $\begin{array}{c}-1.726 \\
(3.185)\end{array}$ & $\begin{array}{c}1.400 \\
(3.775)\end{array}$ & $\begin{array}{c}14.69 \\
(11.54)\end{array}$ \\
\hline pitax & & $\begin{array}{c}-2.949 \\
(2.666)\end{array}$ & $\begin{array}{c}-2.253 \\
(3.158)\end{array}$ & $\begin{array}{c}-6.513 \\
(15.47)\end{array}$ \\
\hline debtgsp & & & $\begin{array}{c}-2.453 \\
(2.381)\end{array}$ & $\begin{array}{l}-2.286 \\
(2.974)\end{array}$ \\
\hline aidgsp & & & $\begin{array}{l}-15.57 \\
(8.511)\end{array}$ & $\begin{array}{l}-9.506 \\
(9.458)\end{array}$ \\
\hline youngshare & & & $\begin{array}{c}-2.775 \\
(4.769)\end{array}$ & $\begin{array}{l}-1.924 \\
(5.611)\end{array}$ \\
\hline oldshare & & & $\begin{array}{l}-6.505 \\
(5.854)\end{array}$ & $\begin{array}{l}-8.317 \\
(6.693)\end{array}$ \\
\hline L.meansalesw & & & & $\begin{array}{l}-24.64^{*} \\
(8.317)\end{array}$ \\
\hline L2.meansalesw & & & & $\begin{array}{c}-6.710 \\
(7.466)\end{array}$ \\
\hline L.rate & & & & $\begin{array}{c}-11.75 \\
(15.21)\end{array}$ \\
\hline L2.rate & & & & $\begin{array}{c}-0.572 \\
(11.31)\end{array}$ \\
\hline L.pitax & & & & $\begin{array}{c}7.318 \\
(21.57)\end{array}$ \\
\hline L2.pitax & & & & $\begin{array}{c}-2.633 \\
(15.35)\end{array}$ \\
\hline L.unem & & & & $\begin{array}{c}5.262 \\
(11.49)\end{array}$ \\
\hline L2.unem & & & & $\begin{array}{c}1.284 \\
(9.371)\end{array}$ \\
\hline L.Ingsp & & & & $\begin{array}{c}4.792 \\
(3.284)\end{array}$ \\
\hline
\end{tabular}




\begin{tabular}{|c|c|c|c|c|}
\hline L2.Ingsp & & & & $\begin{array}{c}-4.634 \\
(3.271)\end{array}$ \\
\hline L.rep & & & & $\begin{array}{l}-0.343 \\
(0.411)\end{array}$ \\
\hline L2.rep & & & & $\begin{array}{l}-0.427 \\
(0.323)\end{array}$ \\
\hline L.dem & & & & $\begin{array}{l}-0.189 \\
(0.362)\end{array}$ \\
\hline L2.dem & & & & $\begin{array}{l}0.0450 \\
(0.279)\end{array}$ \\
\hline$N$ & 1055 & 987 & 946 & 885 \\
\hline
\end{tabular}

Table A6 Probit regressions on probability of lowering corporate tax rate

\begin{tabular}{|c|c|c|c|c|}
\hline & (1) & $(2)$ & (3) & (4) \\
\hline meanrate & $\begin{array}{c}-7.343 \\
(35.35)\end{array}$ & $\begin{array}{c}-27.85 \\
(53.02)\end{array}$ & $\begin{array}{c}-62.69 \\
(59.41)\end{array}$ & $\begin{array}{l}-319.6^{*} \\
(111.9)\end{array}$ \\
\hline unem & $\begin{array}{l}0.0835 \\
(4.229)\end{array}$ & $\begin{array}{c}-1.132 \\
(4.571)\end{array}$ & $\begin{array}{c}3.114 \\
(4.834)\end{array}$ & $\begin{array}{c}9.957 \\
(11.76)\end{array}$ \\
\hline rep & $\begin{array}{c}-0.0868 \\
(0.193)\end{array}$ & $\begin{array}{r}-0.0504 \\
(0.201)\end{array}$ & $\begin{array}{c}-0.0326 \\
(0.222)\end{array}$ & $\begin{array}{r}-0.0889 \\
(0.403)\end{array}$ \\
\hline dem & $\begin{array}{c}-0.283 \\
(0.204)\end{array}$ & $\begin{array}{c}-0.300 \\
(0.209)\end{array}$ & $\begin{array}{c}-0.298 \\
(0.217)\end{array}$ & $\begin{array}{l}-0.184 \\
(0.405)\end{array}$ \\
\hline elecyr & $\begin{array}{c}-0.153 \\
(0.180)\end{array}$ & $\begin{array}{c}-0.155 \\
(0.184)\end{array}$ & $\begin{array}{l}-0.161 \\
(0.189)\end{array}$ & $\begin{array}{c}-0.221 \\
(0.223)\end{array}$ \\
\hline Ingsppc & & $\begin{array}{c}-0.192 \\
(0.349)\end{array}$ & $\begin{array}{l}-0.330 \\
(0.414)\end{array}$ & $\begin{array}{c}-0.963 \\
(0.674)\end{array}$ \\
\hline salesw & & $\begin{array}{r}-0.0251 \\
(0.465)\end{array}$ & $\begin{array}{c}-0.0111 \\
(0.502)\end{array}$ & $\begin{array}{l}-2.061 \\
(1.933)\end{array}$ \\
\hline pitax & & $\begin{array}{l}0.0701 \\
(3.228)\end{array}$ & $\begin{array}{c}3.796 \\
(3.692)\end{array}$ & $\begin{array}{l}-20.25 \\
(14.89)\end{array}$ \\
\hline debtgsp & & & $\begin{array}{c}-0.986 \\
(2.505)\end{array}$ & $\begin{array}{l}-1.061 \\
(3.351)\end{array}$ \\
\hline aidgsp & & & $\begin{array}{c}-12.59 \\
(8.505)\end{array}$ & $\begin{array}{c}-0.143 \\
(10.55)\end{array}$ \\
\hline youngshare & & & $\begin{array}{c}-3.659 \\
(6.669)\end{array}$ & $\begin{array}{l}-5.587 \\
(8.161)\end{array}$ \\
\hline oldshare & & & $\begin{array}{c}7.485 \\
(6.979)\end{array}$ & $\begin{array}{c}4.103 \\
(8.433)\end{array}$ \\
\hline L.meanrate & & & & $\begin{array}{c}243.0 \\
(134.4)\end{array}$ \\
\hline L2.meanrate & & & & $\begin{array}{c}88.07 \\
(126.2)\end{array}$ \\
\hline
\end{tabular}




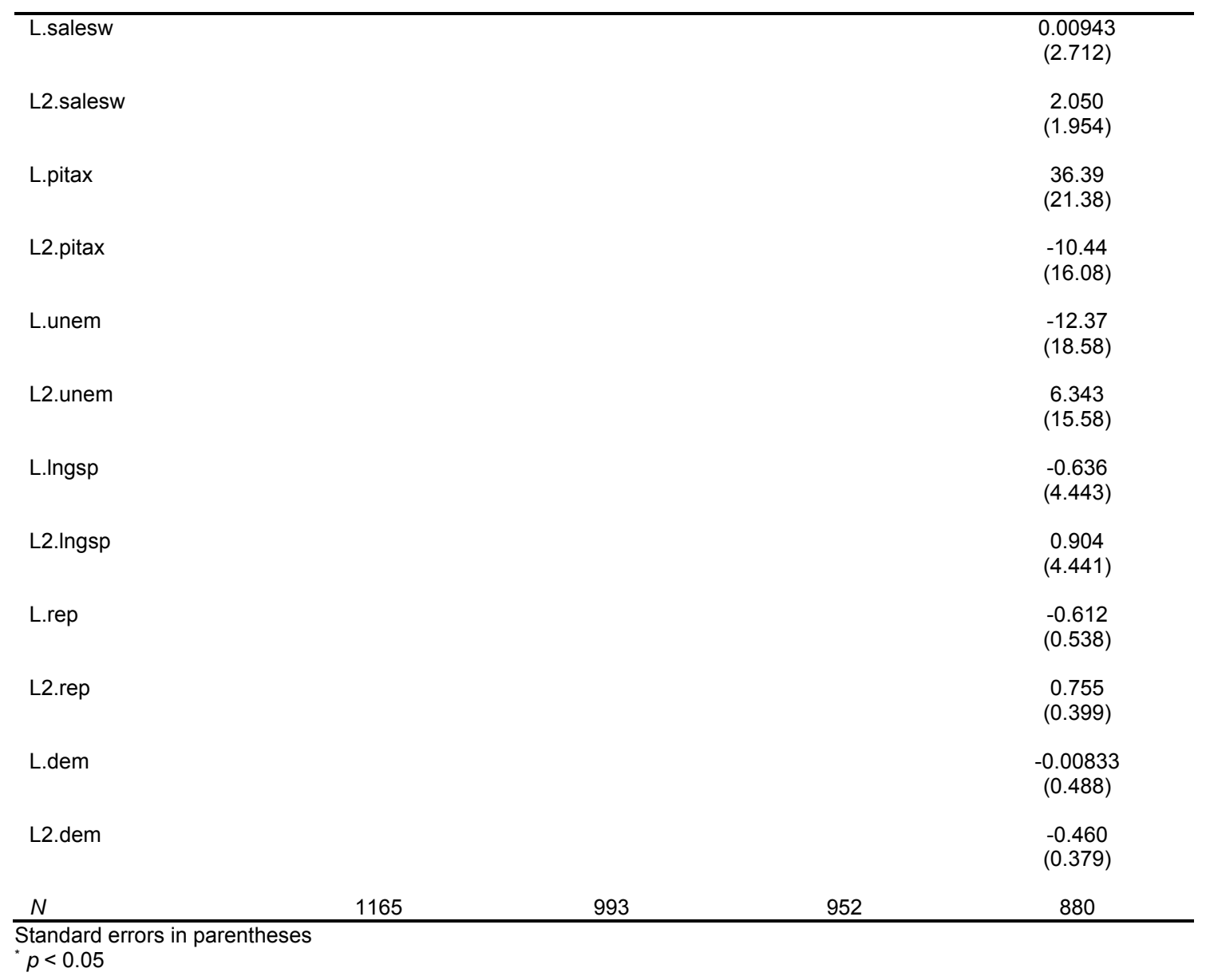




\section{References}

Advisory Commission on Intergovernmental Relations (various years) Significant Features of Fiscal Federalism, Washington DC: ACIR

Anand, B. and Sansing, R. (2000) 'The Weighting Game: Formula Apportionment as an Instrument of Public Policy', National Tax Journal 53(2):183-200

Avi-Yonah, R. and Clausing, K. (2008) 'Reforming Corporate Taxation in a Global Economy: A Proposal To Adopt Formulary Apportionment', in J. Furman and J. Bordoff (eds), Path to Prosperity: Hamilton Project Ideas on Income Security, Education, and Taxes, Washington: Brookings Institution Press

and Durst, M. (2009) 'Allocating Business Profits for Tax Purposes: A Proposal to Adopt a Formulary Profit Split', Florida Tax Review, 9(5): 497-553

Chirinko, R. and Wilson, D. (2010) 'Can Lower Tax Rates be Bought? Business Rent-Seeking and Tax Competition Among U.S. States', National Tax Journal, December 63(4): 867-994

Clausing, K. (2011) 'The Revenue Effects of Multinational Firm Income Shifting', Tax Notes (March 28): 1580-1586

(2009) 'Multinational Tax Avoidance and Tax Policy', National Tax Journal 57 (December): 703-725

_ (2008) 'Closer Economic Integration and Corporate Tax Systems', Global Economy Journal 8(2): 1-22

- (2007) 'Corporate Tax Revenues in OECD Countries', International Tax and Public Finance 14: 115-133

Commerce Clearing House (various years) The Multistate Corporate Tax Almanac, $\mathrm{CCH}$

_ (various years) Multistate Corporate Tax Guide, $\mathrm{CCH}$

_ (various years) State Tax Handbook, $\mathrm{CCH}$

_- (various years) US Master Multistate Corporate Tax Guide, $\mathrm{CCH}$

Cornia, G., Edmiston, K., Sjoquist, D. and Wallace, S. (2005) 'The Disappearing State Corporate Income Tax', National Tax Journal 58(1): 115-138

Crone, T. (2005) 'An Alternative Definition of Economic Regions in the United States Based on Similarities in State Business Cycles', Review of Economics and Statistics 87(4): 617-626

Council of Economic Advisers (2013) Economic Report of the President, Washington DC: US Government Printing Office

Council of State Governments (various years), The Book of the States, CSG 
De Mooij, R. (2005) 'Will Corporate Income Taxation Survive?', De Economist, 153(3): 277-301 and Ederveen, S. (2008) 'Corporate Tax Elasticities: A Reader's Guide to Empirical Findings', Oxford Review of Economic Policy 24: 680-697

DeWaegenaere, A. and Sansing, R. (2008) 'Transfer Pricing, Formulary Apportionment, and Productive Efficiency', Tuck School of Business Working Paper No. 2008-39

Devereux, M. and Loretz, S. (2008a) Increased Efficiency through Consolidation and Formula Apportionment in the European Union?, Oxford University Centre for Business Taxation Working Paper no. 0812

(2008b) 'The Effects of E.U. Formula Apportionment on Corporate Tax Revenues', Fiscal Studies 29(1): 1-33

Edmiston, K. (2002) 'Strategic Apportionment of the State Corporate Income Tax', National Tax Journal 55(2): 239-262

Eichner, T. and Runkel, M. (2008) 'Why the European Union Should Adopt Formula Apportionment with a Sales Factor', Scandinavian Journal of Economics 110(3): 567-89

Fox, W. and Luna, L. (2005) 'Do Limited Liability Companies Explain Declining State Corporate Tax Revenues?', Public Finance Review 33: 690-720

Fuest, C., Hemmelgarn T. and Ramb, F. (2007) 'How Would the Introduction of an EU-wide Formula Apportionment Affect the Distribution and Size of the Corporate Tax Base? An Analysis Based on German Multinationals', International Tax and Public Finance 14(5): $605-26$

Goolsbee, A. and Maydew, E. (2000) 'Coveting thy neighbor's manufacturing: the dilemma of state income apportionment', Journal of Public Economics 75: 125-143

Gupta, S. and Hofmann, M. (2003) 'The Effect of State Income Tax Apportionment and Tax Incentives on New Capital Expenditures', The Journal of the American Taxation Association 25: 1-25

_ Moore, J., Gramlich, J. and Hofmann, M. (2009) 'Empirical Evidence on the Revenue Effects of State Corporate Income Tax Policies', National Tax Journal 62(2): 237-67 June

Hellerstein, J. and Hellerstein, W. (1998) State Taxation, Warren Gorham \& Lamont

Hines, Jr., J. (2010) 'Income Misattribution under Formula Apportionment', European Economic Review 54(1) 108-120

Klassen, K. and Shackelford, D. (1998) 'State and Provincial Corporate Tax Planning: Income Shifting and Sales Apportionment Factor Management', Journal of Accounting and Economics 25(3): 385-406 
Mazerov, M. (2001) The 'Single Sales Factor' Formula for State Corporate Taxes: A Boon to Economic Development or a Costly Giveaway?, Center on Budget and Policy Priorities, <http://www.cbpp.org/cms/index.cfm?fa=archivePage\&id=3-27-01sfp.htm>

Mintz, J. and Smart, M. (2004) 'Income Shifting, Investment, and Tax Competition: Theory and Evidence from Provincial Taxation in Canada', Journal of Public Economics 88: 1149_ 1168

Omer, T. and Shelley, M. (2004) 'Competitive, Political, and Economic Factors Influencing State Tax Policy Changes', Journal of the American Tax Association 26 (s1): 103-126

Pethig, R. and Wagener, A. (2007) 'Profit Tax Competition and Formula Apportionment', International Tax and Public Finance 14: 631-55

Pinto, S. (2007) 'Corporate Profit Tax, Capital Mobility, and Formula Apportionment', Journal of Urban Economics 62: 72-1

US Census Bureau, Annual Survey of Manufacturers <www.census.gov/manufacturing/ask>

US Government Internal Revenue Service (various years) Publication 6149, Washington DC:

IRS Office of Research 


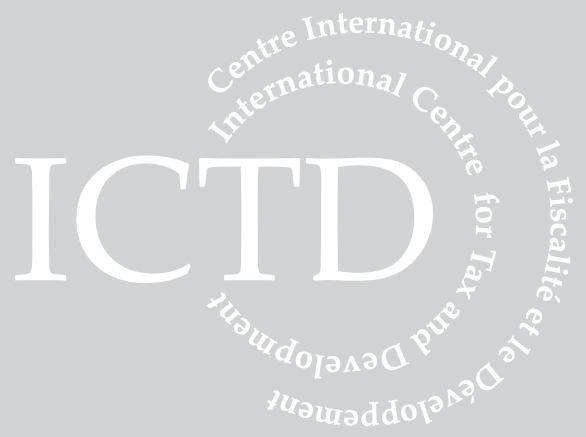

International Centre for Tax and Development at the Institute of Development Studies

Brighton BN1 9RE, UK

T: +44 (0) 1273606261

F: $+44(0) 1273621202$

E: info@ictd.ac

www.ictd.ac 